Portland State University

PDXScholar

Winter 3-28-2019

\title{
RevolutionärInnen am Fließband: a Comparative Gendered Analysis of the 1973 Pierburg and Ford Migrant Labor Strikes
}

Jordan Faith Norquist

Portland State University

Follow this and additional works at: https://pdxscholar.library.pdx.edu/open_access_etds

Part of the European History Commons

Let us know how access to this document benefits you.

\section{Recommended Citation}

Norquist, Jordan Faith, "RevolutionärInnen am Fließband: a Comparative Gendered Analysis of the 1973 Pierburg and Ford Migrant Labor Strikes" (2019). Dissertations and Theses. Paper 4824.

https://doi.org/10.15760/etd.6700

This Thesis is brought to you for free and open access. It has been accepted for inclusion in Dissertations and Theses by an authorized administrator of PDXScholar. Please contact us if we can make this document more accessible: pdxscholar@pdx.edu. 
RevolutionärInnen am Fließband: A Comparative Gendered Analysis of the 1973 Pierburg and Ford Migrant Labor Strikes

\author{
by \\ Jordan Faith Norquist
}

A thesis submitted in partial fulfillment of the

requirements for the degree of

\author{
Master of Arts \\ in \\ History
}

Thesis Committee:

Marc S. Rodriguez, Chair

Patricia Schechter

Richard H. Beyler

Steven N. Fuller

Portland State University

2019 
(C) Jordan Faith Norquist 


\begin{abstract}
In the years following the end of the Second World War, the Federal Republic of Germany experienced a 'golden age' of economic upturn. Due to the labor shortage in the aftermath of war and the division of Germany, West Germany initially looked to its eastern counterpart, the German Democratic Republic, to meet its labor needs in the immediate postwar years. Once East Germany tightened its border control, the Federal Republic of Germany extended bilateral agreements to Southern Mediterranean countries to meet the nation's labor needs. Italy was the first official nation to have a bilateral work agreement with West Germany in 1955 , yet by the end of the labor program, the greatest population of 'guest workers' in West Germany were Turkish nationals. The West German public initially heralded the arrival of guest workers as a boon, but by the program's end in November of 1973, the West German press reviled the Turkish migrant worker as they gradually moved out of isolated company employee barracks into single apartments, often with families or spouses joining them from Turkey. In spite of a lack of rights on West German soil, the year of 1973 was witness to a swell in migrant political activity, in the form of unsanctioned labor strikes.
\end{abstract}

Utilizing two of these strikes, this thesis will compare the strategies, support, opposition, and success of the Ford Cologne (Ford Köln-Niehl) Factory strike and the Pierburg factory strike in Neuss. In both instances, the degree of support by ethnic German coworkers and factory management influenced the success of the strike. Additionally, this analysis will demonstrate that gender, in concert with nationality, negatively affected the results of the Ford Cologne Strike by way of public reception, while the negotiation of the Pierburg strike through a gendered lens aided woman migrant 
workers in the cooperation of factory management, the workers' council, union, and the West German public. Regardless of the strikes' outcomes, the significance of the labor strikes of 1973 is emblematic of both the lack of human rights afforded migrant workers in West Germany at the time and the persistent determination of blue-collar migrant workers to claim space for themselves and their families. 


\section{Dedication}

Für Nataša:

Du hast an mich fast geglaubt und in Dir fand ich eine Mentorin und auch eine Freundin. Ich bedanke mich, für Alles. 


\section{Acknowledgements}

I would like to first thank my husband, Brandon, for his part in making this thesis happen. Though he did not have a hand in its creation, he supported me from more than two thousand miles away for over two years. My sister, mothers and fathers-Jess, Sandy and Carol, Wayne and Brent, respectively_also provided a massive amount of encouragement along the way.

There are few faculty at the Portland State department of history who have not been involved in my work at some point. I have Joseph E. Bohling to thank for a rigorous survey of modern European history. Marc S. Rodriguez, as both my advisor and my supervisor at the Pacific Historical Review, Patricia Schechter for her vast (and indispensable) help in refining my theoretical approach and knowledge of women's transnational history, Richard Beyler for his survey of modern European intellectual theory and philosophy, Laura Robson for an introduction to migration and refugee status in the Middle East and global diaspora, and Katy Barber for help in introducing me to the Master's program — and for simply checking in along the way. I had the pleasure of assisting in undergraduate courses for Rodney Koeneke and George Armantrout and am indebted to them for their examples as educators.

In my second year at Portland State, I had the pleasure of working for the Pacific Historical Review as the Caroline P. Stoel Editorial Fellow. I am grateful to the PHR, as well was the experience and advice of the Editor-in-Chief and Associate Editor, Marc Rodriguez and Brenda Frink. It was through the resources afforded me by the PHR that I was able to complete firsthand archival research in Germany, an undertaking which appeared insurmountable upon taking the first steps. 
I would like to thank the staff at the Dokumentszentrum und Museum für Migration in Deutschland (DOMiD) in Cologne, Germany for welcoming me into their archive — specifically Beate Rieple and Bettina Just for their guidance through the archival database, Dr. Robert Fuchs for his encouragement and advice, and Mika Schäfer for her enthusiasm. I am very grateful for the hospitality and understanding of this amazing team. I hope to be able to work with DOMiD once again.

Lastly, I would like to thank the department chair, Tim Garrison, and the administrative staff, Andrea and Jeff, for their persistent help and guidance. I am overwhelmingly conscious of the amount of resources afforded me during my time at Portland State University and hope to make good on those investments in my future. 


\section{Table of Contents}

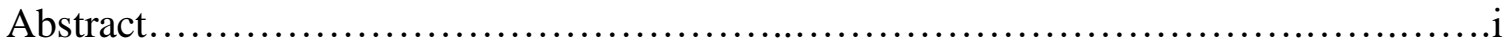

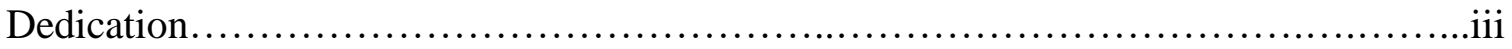

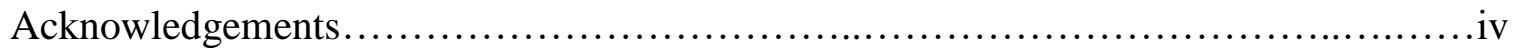

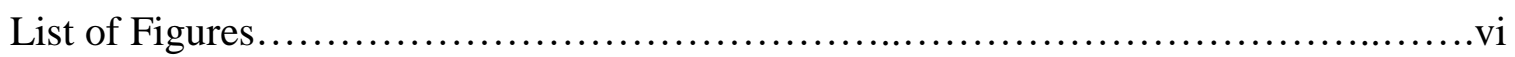

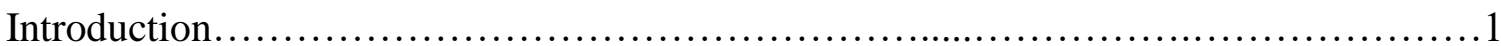

Chapter 1

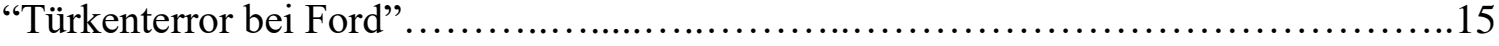

Chapter 2

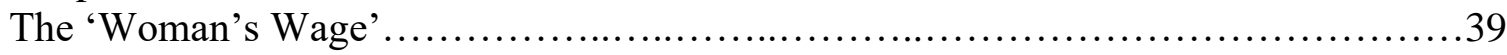

Conclusion

Today's Multikulti?............................................................59

Bibliography........................................................... 65 


\section{List of Figures}

Figure 1. The cover of the July 30, 1973 issue of Der Spiegel.......................5

Figure 2. Political cartoon from Der Spiegel regarding migrant factory housing.......25

Figure 3. Cover of Was tun, featuring Ford Strike leader Baha Targün.................28

Figure 4. List of demands from the Ford Strike from communist periodical, Was tun...31

Figure 5. Political caricature of the Ford Strike, featuring mosque minarets............34

Figure 6. September 3, 1973 cover of Der Spiegel, featuring Baha Targün..............36

Figure 7. Still image from the strike documentary, Ihr Kampf ist unsere Kampf.........52

Figure 8. Flier for the 2005 art installation 'Kanak Attak' in Vienna..................61 


\section{Introduction}

In the wake of the Second World War, Germany found itself in crisis; the economy was in ruins, the political system of the Nazis dismantled, and the German national identity was in question. After the withdrawal of Allied occupation, the main focus of the Federal Republic of Germany was reconstruction and independence.

However, the West German Wirtschaftswunder (economic miracle) of the 1950s was not entirely achieved through German labor and foreign aid: beginning in 1955, foreign workers from southern European and Mediterranean countries bolstered the West German labor force and by the mid-sixties, Turkish workers were the majority nationality of origin among guest workers, the so-called Gastarbeiter. ${ }^{1}$

Beginning in the fifties, West Germany enacted bilateral migrant labor agreements in an effort to solve the rising demand for labor in the face of rapid economic development. These international agreements functioned through contracts between West German companies and the individual migrant worker, and were limited to two-year durations, though most employers ignored this time restriction and those who came to West Germany to work often did not leave. Throughout the fifties and into the midsixties, laborers emigrated from the German Democratic Republic to West Germany for work. In 1955, West Germany expanded its recruitment of foreigners via bilateral labor agreements with Italy, then Spain and Greece in 1960. In 1961, West Germany extended the program to include Turkey, followed by Morocco in 1963, Portugal in 1964, Tunisia

${ }^{1}$ Gastarbeiter or 'guest worker' became the initial nomenclature for foreign workers. By the seventies, the vocabulary shifted to predominantly to Ausländer (foreigners) or foreign employees. As a linguistic change, this highlights the change from West Germans viewing migrant workers as literal guests to emphasizing their foreignness, once the possibility of immigration solidified. 
in 1965, and Yugoslavia in $1968 .{ }^{2}$ East Germany tightened its borders by 1966 (in a bid to stem emigration to the West), leaving the Federal Republic even more reliant on southern European or Mediterranean states for workers.

Temporary contractual agreements between the West German state and the individual migrant worker served as the basis for the Gastarbeiter program. From its inception, the program appeared beneficial for all parties involved. For the host country, the program was a means by which West Germany could source 'cheap' labor to meet the demand of an exponentially growing postwar economy. For the countries sending migrant workers, the program served as an effective way to "export" unemployment and simultaneously receive capital from host countries via remittances. ${ }^{3}$ For Turkey, the justification for sending its citizens abroad for work emphasized the role of on-the-job training. The Turkish state's reasoning was that sending unskilled workers to West Germany on temporary contract would gather dividends when the workers returned to Turkey with a greater degree of skill. However, a 1970 survey of 590 Turkish migrant workers prior to their departure for Germany revealed that instead of the state's projected result, Turkey was instead losing its most-skilled and best-educated workers. ${ }^{4}$

The administration of the program lay mostly with the federal government and on an employer-worker basis. The primary federal overseers of the program were the

${ }^{2}$ Chin also notes in The Guest Worker Question that other countries signed bilateral agreements with West Germany, like Tunisia in 1965 and Korea in 1970, but the number of workers from these countries remained relatively small (Chin, The Guest Worker Question, 37). Se also: Andreas Goldberg, Dirk Halm, and Faruk Şen, Die deutschen Türken (Münster: Lit Verlag, 2004), 3.

${ }^{3}$ West Germany's Gastarbeiter program was not a global exception: during the postwar period and into the latter half of the twentieth century, many Western European countries relied upon foreign labor to match their rising growth.

${ }^{4}$ See Jennifer A. Miller, Turkish Guest Workers in Germany: Hidden Lives and Contested Borders, 1960s to 1980s (Toronto: Toronto University Press, 2018). 


\section{Bundesministerium für Arbeit und Sozialordnung (Federal Ministry of Labor and Social}

Order) and the Federal Institute for Employment. ${ }^{5}$ Employers, trade unions, and some churches and welfare organizations also had a hand in how the program was run in terms of wages, housing, and supporting dependent family members. The work available to guest workers, and increasingly so after 1967, was mostly un-skilled and industrial work: as Ulrich Herbert describes in A History of Foreign Labor in Germany, 1880-1980: "heavy, dirty, dangerous, or generally unpopular kinds of work..." Large populations of guest workers concentrated around large cities—-like Berlin, Munich, Frankfurt, and Cologne - where massive factories and textile mills offered a variety of such 'unpopular kinds of work', or in the case of women workers, where ethnic German women once worked full-time. ${ }^{7}$

As West Germany expanded its geographical reach for more migrant labor, the cultural differences between the ethnic German and the migrant worker became more pronounced in West German society, in particular, for the Turkish worker. For many Germans, newspapers, magazine, television were the major sources by which they grew acquainted with the guest worker, prior to the move of guest workers and their families into single family dwellings. The media perspective of the Turkish worker being "ready to learn and eager to work..." in 1961 had grown pessimistic over the decade that

\footnotetext{
${ }^{5}$ This department was originally formed under the name 'Ministry of Labor' in 1949, later changed to the Federal Ministry of Labor and Social Order, and is currently referred to the Ministry of Labor and Social Affairs in 2018.

${ }^{6}$ Ulrich Herbert, A History of Foreign Labor in Germany, 1880-1980 (Ann Arbor: University of Michigan Press, 1990), 230.

${ }^{7}$ For a deeper look into to gendered labor migration and its relation to the employment of German woman in the postwar era, see: Christine van Oetzen, Teilzeitarbeit und die Lust am Zuverdienen: Geschlechterpolitik und gesellschaftlicher Wandel im Westdeutschland, 1948-1969 (Göttingen: Vandenhoeck \& Ruprecht, 1999).
} 
followed. ${ }^{8}$ The July 30, 1973 edition of Der Spiegel featured a cover photo of a Turkish family with five young children, peering out of a cramped apartment window, with the heading, "Ghettos in Deutschland: Eine Million Türken" ("Ghettos in Germany: A Million Turks"). ${ }^{9}$ In the featured article, "Die Türken kommen—rette sich, wer kann" (“The Turks are Coming—Rescue Yourself, if You Can"), the article describes the development of Turkish communities in German cities like Berlin, Munich, and Frankfurt as potential hotbeds for criminal behavior and social 'misery', envisioned by the author to become as 'troubled' as the United States' Harlem, with an emphasis on the dependents the Gastarbeiter (presumably married men) brought with them. ${ }^{10}$

Through articles like this example, a heightening fear of a cultural 'invasion' and an inundation of economically 'passive' family members is evident. The unnamed author of this article sensed that these "foreign employees" were not as temporary as the West German state previously had promised, stating that this idea was a "fiction," and that the example of Kreuzberg's "takeover" was "prophetic" of events to come. ${ }^{11}$ After the Anwerbestopp (the recruitment ban of migrant workers) on November 23, 1973, the fear of the German public focused on the permanence of migrant workers and their families after the program's end. It was unclear at the time whether or not the Anwerbestopp was permanent. According to the Ministry of Labor, the 1973 Oil Crisis hampered economic development in industrial trades and stated that "the government [could not] justify lifting the ban". ${ }^{12}$ It is crucial to emphasize that prior to the Anwerbestopp, the migrant worker's

8 “Germany Imports Turkish Workers." New York Times, Oct 30, 1963: 53.

${ }^{9}$ Der Spiegel, 31/1973 (July 30, 1073). Note: All translations from original German are the author's translation, unless otherwise noted.

${ }^{10}$ Ibid., 24.

${ }^{11}$ Ibid., 26.

${ }^{12}$ Kurt Steves, “Anwerbestopp bleibt bestehen,” Die Welt, June 13, 1974. 
position and status in West Germany was not in question: guest laborers worked on a temporary basis, under the assumption that they eventually would return to their country of origin. The integration question followed the recruitment ban in 1973, yet the fear of an 'invasion' was rooted in the nearly twenty-year span of the Gastarbeiter program, intensifying with the prominence of Turkish workers within the program by the seventies.

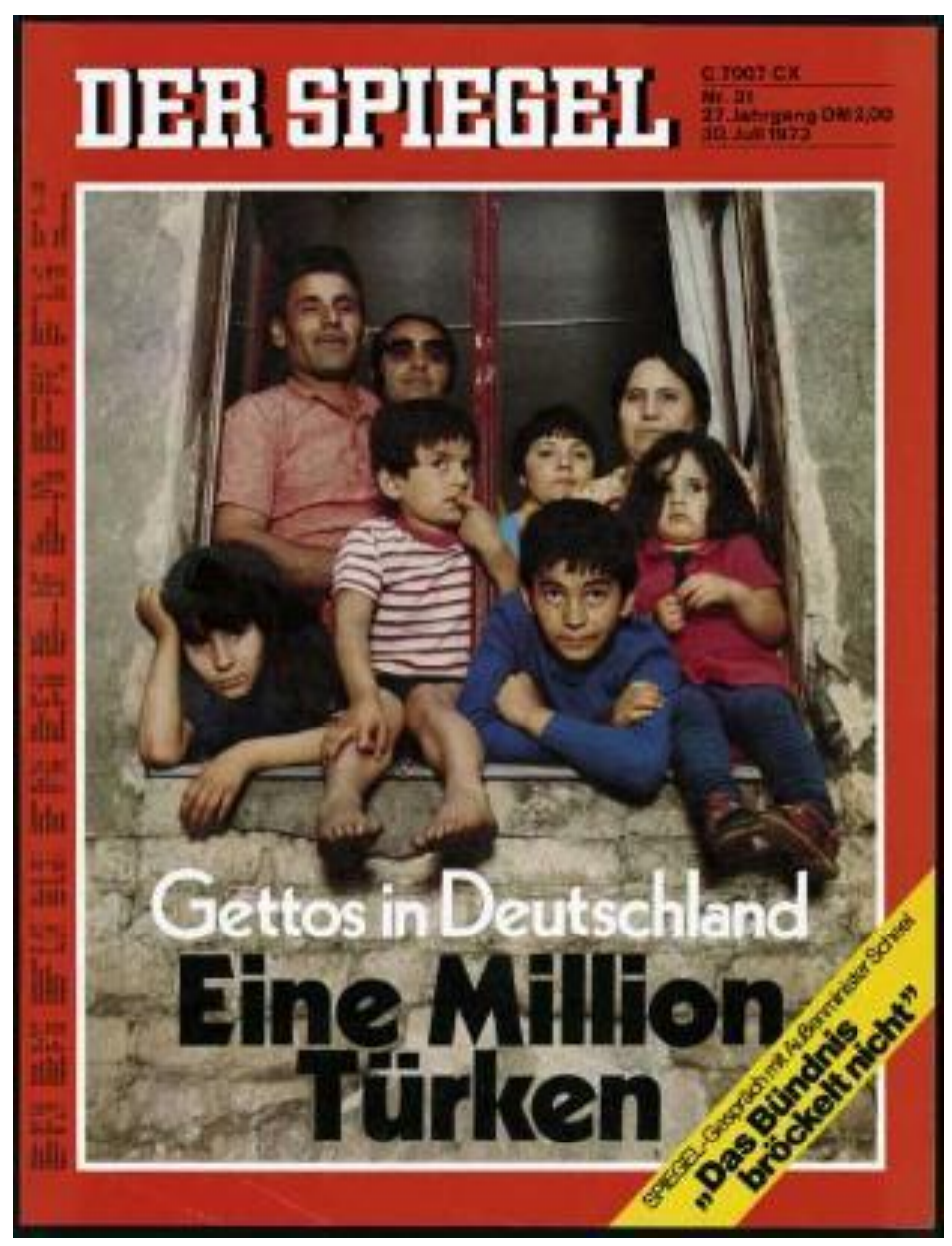

Figure 1. The cover of the July 30, 1973 issue of Der Spiegel. Accessed at Der Spiegel Online Archive.

In 1974, the state determined that forbidding the families of guest workers from joining those working in the Federal Republic of Germany was a violation of their human rights, even though those guest workers were not contractually entitled to the rights of 
German citizens. As Turkish families began to reunite in West Germany in 1974, the myth of the guest workers' "return trip" (Ruckkehr) shattered while the development of the trope of the passive 'tag-along' wife took root. ${ }^{13}$ The possibility of integration, which was unthinkable at the beginning of the 'guest worker' program, became a demonstrable certainty.

West Germans began to question what was to be done with the foreign population within the state and whether or not they had to (or should) grant citizenship to those still in the Republic. The implementation of Ausländerpolitik (foreigner policy) as a tangible framework as integration began with the majority political party, the Christian Democratic Union, issuing the Konzept der CDU Ausländerpolitik in $1977 .{ }^{14}$ Though the document generated by Christian Democrats marks the first step toward citizenship for migrant laborers within the state, the language of the text was still too vague to offer a concrete solution and thereby highlighted the question of what it meant to be 'German'.

The Grundgesetz der Bundesrepublik Deutschland (Basic Law of the Federal Republic of Germany), enacted in May 1949, contained little language describing what a 'German' was in the Federal Republic of Germany. In Article 116, "Definition of "German" - Restoration of Citizenship", a German was described as "a person who possesses German citizenship or who has been admitted to the territory of the German Reich within the boundaries of December, 311937 as a refugee or expellee of German ethnic origin (Volkszugehörigkeit, belonging to das Volk) or as the spouse or descendant

${ }^{13}$ See: Mattes, Gastarbeiterinnen in Deutschland, 206.

${ }^{14}$ Christian Democratic Union of the Federal Republic of Germany, Konzept der CDU Ausländerpolitik (Bonn, 1977). 
of such person". ${ }^{15}$ According to this description, West German citizenship was based upon both jus sanguinis and jus soli, meaning that citizenship could be claimed either via ethnic, or via blood-relation to an already established citizen or through acceptance by naturalization. The designation of migrant workers as 'guests' "served to differentiate those who belonged to the nation and those who did not," emphasizing that while they were "physically present on German soil", migrant workers were irreversibly "separate from the social body" and exempt from the rights of citizens. ${ }^{16}$

Despite the legal vagueness, many West Germans noted cultural and religious difference as an underlying connection within the ethnic German Volk and the German Kulturgut (cultural assets). In demonstrating the incompatibility of the migrant worker (specifically the Turk), many pointed to the treatment of Turkish women as the litmus test for successful integration into West German society and citizenry. ${ }^{17}$ In the late seventies to early eighties, reports from various state ministries and institutes began to focus upon the condition of the 'foreign woman', especially the wives of foreign employees. ${ }^{18}$ According to these reports, foreign women and wives of guest workers were more likely to be subject to isolation and oppression by their families and husbands. These reports found that while this type of gendered separation may have actually

${ }^{15}$ Grundgesetz der Bundesrepublik Deutschland, Art. 116(1).

${ }^{16}$ Chin, The Guest Worker Question: 48.

${ }^{17}$ As the following chapter on the Pierburg strike will demonstrate, this argument fell flat when framed against the prominent role southern Mediterranean women in migrant labor activism.

${ }^{18}$ Chin notes two major reports in The 'Guest Worker' Question in Germany, namely the 1977 report from Franz Brandt, the Federal Minister for Youth, Families, and Health, entitled Situationanalyse nichterwerbstätiger Ehefrauen ausländischer Arbeitnehmer in der Bundesrepublik Deutschland (Bonn: Bundesminister für Jugend, Familie, und Gesundheit, 1977) and Ute Welzel, ed., Situation der Ausländerinnen: Fachtagung am 19.-21. September in Berlin (Berlin: Institut für Zukunftsforschung, 1981). 
contributed to increased female liberty within the familial hierarchy in their home villages, migrating to a foreign country without a similar social structure increased alienation and oppression for these Turkish women. The transformation of the rural, mostly agrarian household in eastern Anatolia as a result of labor migration to West Germany represented a shift in gender roles: with the male head-of-household removed from the day-to-day management of the home, Turkish wives assumed most of the household's decision making and immediate financial decisions. ${ }^{19}$ In contrast to this unintentional empowerment, rural Turkish women removed from their social support circles - either by accepting work in West Germany or by migrating to join a spouseexperienced disenfranchisement. The German state justified their stance on foreigners living in West Germany by utilizing such sociological reports on the welfare of the Turkish woman to prove the Turks' social incompatibility.

Given the sociopolitical climate regarding migrants and migrant workers boiling over into the early seventies, guest workers began to push back, even though they had no legal ground on which to stand. While the primary draw of the guest worker program for foreign laborers was the opportunity to earn more than they could have in their origin country and to improve quality of life for themselves and their families, many felt as though they were an exploited community within the labor force. The Ministry of Work and Social Affairs viewed the guest worker program as an additional, extranational source of labor, not in competition with West German workers. Due to the preference of

${ }^{19}$ Deniz Kandiyoti, "Rural Transformation in Turkey and its Implications for Women's Status" in Women on the Move: Contemporary Changes in Family and Society, UNESCO., and International Meeting of Experts on Research on the Status of Women, Development and Population Trends. eds. (Paris: UNESCO, 1986), 23-4. 
German labor over migrant, guest workers were the 'last hired, first fired' during times of crisis and simply could not make enough money to move back to their country of origin and live comfortably, as promised by recruiters and their own government. ${ }^{20}$

Throughout the duration of the guest worker program, the options for guest workers to advocate for increased rights or secure employment within the workplace were limited. Since guest workers were viewed by the West German state and their employers as separate from West German coworkers, they did receive equal representation from labor unions and the workers' councils elected at the workplace often did not take on migrant labor specific issues. Arguably, the only option available to guest workers was to strike. Since these 'migrant' strikes were not approved through the proper channels, they were deemed 'wildcat strikes', or 'spontaneous strikes' by management and the media. Since guest workers did not have similar representation through labor unions and workers' councils often ignored migrant-specific complaints, there was not an official channel for guest workers to go through from the start. What was to be the last year of the program, 1973, witnessed a swell of migrant labor strikes nationwide. Strikes headed by guest workers occurred throughout the program, notably in 1966-67, yet the final year of the Gastarbeiter program reflected a major uptick in the rate of occurrence. The migrant labor strikes of 1973 were originally intended to be, in part, a labor movement to reform the guest worker program. Instead, as the program ended in late

${ }^{20}$ The economic crisis of 1966-7 was one such significant stress point on the guest worker program and some scholars point to this moment in time as the catalyst for the following labor strikes, leading up to the Anwerbestopp. For more information on unemployment of guest workers, see: Irena Kogan, "Last Hired, First Fired? The Unemployment Dynamics of Male Immigrants in Germany," European Sociological Review 20 (2004):445-461. 
1973, the movements informed the debate surrounding what was to be done with the migrant laborer in Germany: integration or compelled expulsion?

The most publicized strike occurred at the Ford Automobile Factory in the Niehl district of Cologne (Köln) between August 24 and 30, 1973. The media depiction of the migrant workers in this strike, however, was damaging to public reception and focused largely on the nationality of the guest workers, which was almost exclusively Turkish. The September, 10, 1973 issue of Der Spiegel referred to the protest as the “Turks' Strike," framing the event as a selfish money-grab at the hands of foreigners, instead of as beneficial for all Ford assembly line employees. ${ }^{21}$ Without seeking the understanding of why migrant workers required extended vacation time, as well as the reason why Turkish workers at Ford appeared as the most disgruntled employees, West Germans viewed the workers' list of demands as unwarranted or the product of lazy, yet entitled Gastarbeiter. In reality, the types of work assigned to Turkish works in opposition to West Germans - where guest workers were concentrated on end assembly and West Germans filled most management positions—-solidified the image of the 1973 Ford Strike as mainly 'Turkish'. The media portrayal also alienated the Turkish workers from ethnic Germans who worked on the same assembly lines. Since the vacation benefits the striking Turkish workers sought did not extend to the rest of the workforce, it was difficult to generate solidarity, let alone sympathy, from German workers at Ford. ${ }^{22}$ Ultimately, Ford

21 “TÜRKEN-STREIK: Faden gerissen.” Der Spiegel, September 10, 1973.

${ }^{22}$ A primary demand of the Turkish workers on strike was an increase in vacation time for employees who travelled to Turkey-from four weeks to six weeks. 
management met the strike with hostility; Ford did not only ignore the list of demands in full, but an additional one hundred workers were terminated and six hundred quit. ${ }^{23}$

In contrast, the strike at Pierburg Neuss automobile parts factory between August 13 and 18, 1973, only ten days prior to the Ford Strike, was significantly more successful and better received at most management, local, national, and global levels. The (predominantly) migrant women who organized the strike had a central demand of the factory management: the abolition of "wage group II", a wage bracket that only applied to women, regardless of the intensity of their work on the assembly line. The abolition of wage bracket II, however, would be automatically accompanied by a one Deutschmark raise per hour, in order to match the wages of their male counterparts. Many scholars point towards the way in which the women on strike negotiated their gender to the movement's advantage as the key to its success, yet migrant women were in the majority. Why, then, were those on strike at Pierburg referred to by gender than by race? The last chapter of this thesis, dedicated to the analysis of the Pierburg strike, will demonstrate that the intensive communication throughout the factory labor force and unity between migrant and ethnic German workers deemphasized their role as the southern Mediterranean 'Other', along with a gendered political framework.

While the most recognizable photograph of a Gastarbeiter is that of Armando Rodrigues and the most commonly cited migrant labor protest is the Ford Cologne Factory Strike, the Pierburg Strike of 1973 provokes questions about the agency of migrant women. A strike organized by woman migrant workers challenges the image of the Turkish woman migrant in German society that developed after the Anwerbestopp,

\footnotetext{
${ }^{23}$ Huwer, "“Gastarbeiter' im Streik”, 241-42.
} 
one year later - especially when framed against the failure of the Ford Strike of August 1973. The importance of this image was essential to the debate on integration and the "guest worker question" in West German society after the end of the guest worker program.

The willful forgetting of the image of the pre-1973 Gastarbeiterin demonstrates the flawed rationale of those in media and politics who pointed to the stereotyped treatment of Muslim-Turkish women as the litmus test for the ability of Turks to integrate into German society. The women of Pierburg complicate this image, and their successful navigation to the abolition of Leichtlohngruppe II demonstrates that migrant (Turkish) women cannot be lumped into one group as "oppressed," and that scholars must recognize the importance of the woman migrant worker in labor history, as well to their importance in shaping (West) German politics and citizenship.

The Pierburg and Ford Strikes were short in comparison to other labor movements in 1973 , yet the media closely followed and widely circulated the events in Neuss and Cologne, West Germany. An entire issue of the Der Spiegel in December of 1973 retold the events of 'Wilde Streiks' affecting Germany during the year and the precarious situation major industrial groups and trade unions, like IG Metall (the major German metalworkers' union), found themselves in with their predominantly foreign workforce. ${ }^{24}$ Television journalists Luc Jochimsen and Lucas Maria Böhmer reported on the status of the strike on the ARD broadcasting channel, stating that "women are the Reservearmee and (reserve army) of the economy...they are 'hired and dismissed as they (employers) see fit"”. Jochimsen and Böhmer suggest that this strike was "a historic situation", one

\footnotetext{
24 “Wilde Streiks: Lohnpolitik auf eigene Faust,” Der Spiegel, September, 31973.
} 
where these woman migrants refused to "let themselves be intimidated and fought for their rights through solidarity". ${ }^{25}$ At the time, it appeared that Germans rallied around these migrant workers and supported their demands for greater representation and equality in the workplace. However, this reception of the (woman) migrant worker was not the only perspective at the time: as the possibility migrant integration loomed in the future, many West Germans began to question what constituted a German, demonstrating that the workers at Ford experienced more direct societal backlash as a result of the media's emphasis on their nationality. Instead, West Germans attributed the success of the Pierburg strike to the unity of women in the workplace, rather than migrant political mobilization.

Immigrant labor strikes in the Federal Republic were not limited to 1973, yet this year marked a steep increase in the number of well-documented high profile wildcat strikes in West Germany. The final labor strikes organized by Gastarbeiter, many of which were Turkish migrants, challenged the assumption of the German state that foreigners held little political and societal authority, but they also represent a gender dynamic that has yet to be analyzed in full. By comparing the 'wildcat' strikes at the Alfred Pierburg Automobile Parts Factory in Neuss and the Ford Factory in Cologne, gender proved beneficial to the women at Pierburg and detrimental to the men at Ford, yet assumed traditional gender roles ultimately proved damaging to historical accounts of the Gastarbeiterin (woman migrant worker). While woman migrant workers at Pierburg emphasized gender inequality within the factory (since West German women and migrant

25 "Diese Woche im Fernsehen: Ihre Geduld geht zu Ende,“ Der Spiegel, December, 17 1973. 
women were all included in the same 'light industrial wage bracket'), the inequality between migrant and West German workers at Ford Cologne Niehl along national and ethnic lines was more pronounced. However, gender did play a role in the Ford Strike, predominantly in the media representation and critical reception of male Turkish workers during and after the strike.

Considering that the 'guest worker' program began less than sixty years ago, the historiography of postwar labor migration in West Germany is still relatively young. The transnational nature of labor migration history also contributes to a lack of scholarship on the Gastarbeiter program, as primary sources (and the former workers themselves) exist between multiple states. The status of the migrant worker as a liminal figure in West German society also delayed serious inquiry into their contribution to German history. In the past fifteen years, a small number of German, Turkish, and American have begun to address the economic, social, and political import of the Gastarbeiter/rin, instead of interpreting the presence of the migrant worker as auxiliary to (West) German history. ${ }^{26}$

\section{Chapter 1}

${ }^{26}$ Please note that this comparison does not follow a chronological timeline between chapters. The framework behind this stylistic choice is to emphasize the publicized nature of the Ford Strike in Cologne and its brutal ending, then introduce a lesser-known-yet just as significant-strike that happened weeks prior. By following this outline, the argument juxtaposes the critical reception of each strike and underlines the racialized and radicalized language of the media's coverage of the later Ford Cologne Factory strike. 


\section{"Türkenterror bei Ford": Origins and Public Reception of the 1973 Ford Cologne Factory Strike}

The presence of the migrant laborer is undeniably integral to the history and industrial development of West Germany after the state signed the first bilateral labor agreement in 1955. But as other scholars have argued, the advent of integration in the seventies and eighties has erased key aspects of the guest worker as a West German historical actor, specifically in relation to the way in which foreign workers navigated through West German economic, social and political spheres. ${ }^{27}$ Though foreign workers came from a number of southern Mediterranean nations, many scholars within the field of West German migration history argue that Turkish guest workers experienced a higher degree of scrutiny. ${ }^{28}$ Hiring offices in Istanbul promised those interested in joining the Gastarbeiter program in West Germany would enjoy the same legal rights as the West German worker, yet the reality was grim..$^{29}$ The legal rights of the guest worker were mostly limited to those contained within their agreement with West German employers and trade unions resisted the inclusion of foreign workers within their ranks. West Germany adopted a policy of preferential hiring of Germans over foreign workers, referred to as Inländerprimat (resident priority). ${ }^{30}$

${ }^{27}$ Simon Goeke, "The Multinational Working Class? Political Activism and Labour Migration in West Germany During the 1960s and 1970s," Journal of Contemporary History 49 (2014): 160-182.

28 . This was in part due to religious differences, where the majority of Turks observed Islam. Other guest workers came from countries with Christian religious majorities, such as Italy, Greece, and Yugoslavia. West Germans considered religion to be one of the elements of das Volk. See Karen Schönwälder, "Migration, Refugees and Ethnic Plurality as Issues of Public and Political Debates in (West) Germany", in Cesarani and Mary Fulbrook eds, Citizenship, Nationality and Migration in Europe (New York: Routledge, 1996), 166-9.

${ }^{29}$ Miller, Turkish Guest Workers, 138-9.

${ }^{30}$ Goeke, 161. 
The ways in which migrant laborers could protest or advocate for fairer wages, improved living conditions, and for inclusion in social welfare like Kindergeld. ${ }^{31}$ Yet for near the entirety of the guest worker program, foreign workers engaged in sociopolitical labor activism, both legally and illegally. Since migrant laborers arrived in West Germany for primarily economic reasons, the most common form of activism foreign workers engaged in was the labor strike; when guest workers formed their own strikes without the permission of workers' councils (Betriebsräte) or trade unions, these were considered 'wildcat' strikes and therefore illegal protests.

Arguably the most publicized (and demonized) labor strike in West German history was the Ford Cologne Factory strike in August of 1973. After around three hundred migrant workers were fired by Ford management for failing to return from vacation on time (all Turks), Turkish Ford workers responded with outrage. Many argued at the time that this delay in returning to work was not due to impertinence or carelessness, but because of the long travel time between Germany and Turkey via ground transportation, which many foreign workers preferred to train or air travel for the lower cost and the ability to carry more West German goods home to Turkey. The conditions on guest worker trains between Istanbul and West Germany also informed many Turkish migrant workers' travel preference. ${ }^{32}$ Though the strike began in protest of

${ }^{31}$ Kindergeld was a colloquial term for a West German program that provided financial support for families with children; the word literally translates as "child-money'.

${ }^{32}$ As Jennifer A. Miller discusses in her article "On Track for West Germany: Turkish 'Guest-worker' Rail Transportation to West Germany in the Postwar Period," the conditions on the 'Hellas-Istanbul' Express were near intolerable: cramped, unsanitary, and more akin to "cattle transport" than the luxury of a "German train" (550). See Miller, "On Track for West Germany: Turkish 'Guest-worker' Rail Transportation to West Germany in the Postwar Period," German History 30 (2012): 550-73. 
this mass termination of migrant contracts, living conditions, unequal pay, and workplace discrimination served as the motivating factors of the strike.

The following details the rights of the foreign worker and origins of migrant activism in West Germany. Central to this argument is the case study of the August 1973 wildcat strike at Ford in Cologne, given the living and working conditions of the 'guest' workers at Ford, the events of the Ford strike and the public reaction thereto, especially through the media. This chapter argues that the lack of legal and political rights afforded foreign laborers, a lack of solidarity on the part of the German Ford worker and trade unions, and the demonization of the strike in local and national media greatly impacted this event in (West) German history.

\section{Historiography}

The historiography of migrant workers in West Germany-Turkish or otherwise - commits a fair amount of thought toward the consideration of the migrant's legal rights, yet many works do not go in depth when analyzing individual strikes, nor the political background of the migrant worker prior to entry into Germany. While the 1973 wildcat strike at Ford is by far the most cited example of migrant labor activism in the historiography due to its widespread media coverage, the build up to and the fallout of the strike is simplified or underrepresented. In the recent Turkish Guest Workers in Germany: Hidden Lives and Contested Borders, 1960s to 1980s, Jennifer A. Miller takes little more than one page to discuss the entirety of the August 1973 strike at Ford Köln. ${ }^{33}$

${ }^{33}$ Miller, Turkish Guest Workers, 144. Note: In all fairness, the purpose of Miller's book is not to solely assess political activity among Turkish Guest Workers and indeed spends more time considering the events of the August 1973 Pierburg strike in Neuss, West Germany, only 40 
While Miller's work attempts to illustrate the whole of the Turkish experience during the Gastarbeiter program, the lack of analysis devoted to migrant activism portrays the integration of Turks into West German society more as an inevitability than it truly was. In fact, migrant activism need not be tied to integration: in 1973, the goal of the Turkish worker was more aligned to increasing quality of life, both in the workplace and in society, instead of seeking citizenship.

The debate throughout the latter half of the twentieth century, however, was whether or not foreign nationals were entitled to the same amount of representation and equality to that of their West German colleagues. ${ }^{34}$ An earlier work by Karin Hunn, entitled "Nächstes Jahr kehren wir zurück...": die Geschichte der türkischen "Gastarbeiter" in der Bundesrepublik presents a similar argument, but with more emphasis on how migrant workers were trapped in West Germany by the guest worker system that brought them to the country. Hunn posits that many former guest workers felt that they simply could not make enough money to make the return trip home and instead brought their families to West Germany to create a more stable and unified home environment. Therefore, guest workers did not have the initial purpose of moving to West Germany to immigrate, but they had little choice once they realized that travel between Turkey and West Germany was not financially sustainable.

kilometers northwest of Cologne. Additionally, Miller previously published an article dedicated to the discussion of labor activism. See: Jennifer A. Miller, "Her Fight is Your Fight: 'Guest Worker' Labor Activism in the Early 1970s West Germany," International Labor and WorkingClass History, No. 84 (Fall 2013): 226-47.

${ }^{34}$ See: Karin Hunn, "Nächstes Jahr kehren wir zurück...": die Geschichte der türkischen "Gastarbeiter" in der Bundesrepublik (Göttingen: Wallstein, 2005). 
Huwer’s “'Gastarbeiter’ im Streik: Die spontane Arbeitsniederlegung bei Ford Köln im August 1973" represents the most detailed account of the 1973 Ford Strike. ${ }^{35}$ Lena Foerster’s “Zwischen Integration und Rückkehrförderung—türkische Arbeitnehmer bei den Kölner Ford-Werken 1961-1983” expands upon Huwer's account of this event in West German labor history. ${ }^{36}$ These two articles are effective in forming a complete background to the strike, including the pressures and inequalities Turkish workers at Ford faced every day, interpreting the actions and demands of the primarily Turkish men on strike. By highlighted the lack of representation for the Turkish population of workers on the workers' council, these works explain how the dichotomy between the foreign worker and German employee served as a contributing factor in the development of the strike. According to Foerster, the majority of Turks worked on the most strenuous and dangerous section of the assembly line (Endmontage, or 'final assembly'), whereas the majority of factory management and supervisors were German. ${ }^{37}$ Peter Birke's dissertation, later published as a monograph, entitled Wilde Streiks im Wirtschaftswunder: Arbeitskämpfe, Gewerkschaften, und Soziale Bewegungen in der Bundesrepublik und Dänemark, details the extent of the spontaneous strikes in 1973 and their ramifications in West German society. ${ }^{38}$ Though the work is a comparative analysis

35 Jörg Huwer, “'Gastarbeiter' im Streik. Die spontane Arbeitsniederlegung bei Ford Köln im August 1973," Geschichte im Westen (GiW) Vol. 22 (2007): 223-49. This text was originally published as an article in 2007 and later developed into a book in 2013 with the help of the Dokumentationszentrum und Museum über die Migration in Deutschland (DOMiD), an archive in Cologne, Germany.

${ }^{36}$ Lena Foerster, "Zwischen Integration und Rückkehrförderung — türkische Arbeitnehmer bei den Kölner Ford-Werken 1961-1983," Geschichte in Köln 61, No. I (2015): 237-70.

${ }^{37}$ Ibid., 253-4.

${ }^{38}$ Peter Birke, Wilde Streiks im Wirtschaftswunder: Arbeitskämpfe, Gewerkschaften, und Soziale Bewegungen in Der Bundesrepublik Und Dänemark (Frankfurt: Campus, 2007). 
of labor rights conditions in both West Germany and Denmark, it is groundbreaking in its contribution to the emphasizing the correlation between social movements to economic developments and crises, especially for the migrant workers western European countries employed. In this work, Birke provides the antecedents to the strikes of 1973 and why guest workers chose the 'wildcat strike' as a means for gaining rights and pay more comparable to that of their West German coworkers. According to Birke, the lack of representation of foreign workers by trade unions like IG Metall and the miniscule amount of Turkish or migrant representation at the factory level pushed migrant workers to engage in 'illegal strikes', simply because they did not have the right to legally strike. The comparisons between two western European countries during the postwar boom-andbust reveals that West Germany was not alone in its implementation of migrant labor as a means for economic recovery and expansion: in fact, migrant labor was more of the standard for northern and western Europe, rather than an aberration. However, the relationship between the West German guest worker and the state differed from all other European host countries. While other countries, like Britain, France, and the Netherlands, employed "colonials or postcolonials", granting them rights "of entry, work, residence, and even citizenship in the metropole." 39 As the term Gastarbeiter suggests, these migrant laborers were guests, not integrated members of West German society, so their rights on German soil were limited to their economic contribution

\section{Legal Rights of the 'Guest' Worker}

${ }^{39}$ Rita Chin, "Turkish Women, West German Feminists, and the Gendered Discourse on Muslim Cultural Difference," Public Culture 22 (2010): 560. 
West German factories were dependent on migrant workers from the beginning of the labor program, from 1955 until its end in late 1973. In 1961, when Turkey and West Germany first formed a bilateral labor agreement, Ford afforded some accommodations to Turkish workers, in an effort to make their factories more attractive to the prospective laborer: teaching German language at the workplace (labeled "Deutsch am laufenden Band' by Ford PR officials), as well as offering Muslim Turks pork-free meal options at the company's canteen and allowing workers breaks to pray during the day in an "unofficial" prayer room. ${ }^{40}$

At the workplace, foreign guest workers enjoyed similar labor rights as ethnic German workers, yet their social and economic rights did not extend far beyond factory gates. Due to the individual-to-employer basis of guest worker contracts, guest workers possessed few, if any legal or political rights. As defined by the European Convention on Establishment of December 13, 1955, West Germany reserved the right to decide who was allowed into the country and whom they could expel, with impunity. ${ }^{41}$ Elements of the West German Aliens Act of April 28, 1965 are similarly vague, specifically in regards to the terms outlining cause for expelling foreign workers. If a migrant worker was found to "prejudice important interests of the Federal Republic," he or she may be subject to deportation, yet this vague language allows the government a great deal of discretion when determining what these prejudicial trespasses may be. ${ }^{42}$ As such, the major anxiety for the guest worker was in the uncertainty of their presence in West Germany.

\footnotetext{
${ }^{40}$ Huwer, “'Gastarbeiter' im Streik,” 229. See also: Foerster, 242-3.

${ }^{41}$ Fritz Franz, "The Legal Status of Foreign Workers in the Federal Republic of West Germany," in Manpower Mobility across Cultural Boundaries: Social, Economic, and Legal Aspects: The Case of Turkey and West Germany, ed. R.E. Krane (Leiden, Netherlands: Brill, 1975), 49.

${ }^{42}$ Franz, 51.
} 
By 1973, 'guest' workers represented nearly twelve percent of the West German labor force, with 12,000 Turkish migrants working at Ford Cologne Niehl alone. ${ }^{43}$ Yet their representation in labor and trade unions was not reflective of this percentage. In regards to the example of Cologne, around two in three Turkish men working in the city worked at the Ford Cologne Factory. ${ }^{44}$ While Jorg Hüwer claims in “"Gastarbeiter' im Streik" that migrant workers were entitled to the same rights as native Germans in the workplace, the Inländerprimat policy touted by trade unions allowed and promoted the employment of West Germans over foreign laborers. ${ }^{45}$ West German trade unions were limited to the umbrella organization for trade unions, Deutscher Gewerkschaftsbund (DGB), and targeted, affiliated groups like IG Metall (specific to metalworkers). This meant that opportunities for independent union formation were not a reality in West Germany and guest workers were left unrepresented, whereas their German coworkers were.

\section{Migrant Activism in the Bundesrepublik}

According to Simon Goeke, the majority of activism undertaken by migrants in their early years of West German residency focused on protesting the political regimes of the workers' country of origin. ${ }^{46}$ West German officials in regions densely populated

\footnotetext{
${ }^{43}$ Ibid. See also: Lena Foerster, “Zwischen Integration und Rückkehrförderung”: 238.

${ }^{44}$ Huwer, 225.

${ }^{45}$ Goeke, 161.

${ }^{46}$ Goeke, 161.
} 
with guest workers worried that student activism would agitate and mobilize foreign workers into political activism. ${ }^{47}$ (By 1961, over fifteen percent of foreign students at universities in West Germany were of Turkish origin, roughly thirteen hundred in total.) $)^{48}$ Both Turkish and German governments reacted to student activism in West Germany. In 1969, Hakki Keskin, a political science student at the Freie Universität in Berlin, gave a speech in front of the Turkish Embassy alongside sixteen other students. The speech, "condemning censorship and inequalities of wealth in Turkey," spurred the Turkish government into revoking Keskin's student visa. ${ }^{49}$ While Turkey was more concerned with the conduct of Turkish nationals abroad and the international image of the state, West German anxieties lay with the possibility of student activism mobilizing foreign workers.

However, the migrant worker did not need external inspiration to engage in political activism and the Ford Köln-Niehl strike of August 1973 did not exist in a vacuum. On April 30, 1962, 300 Turkish workers in Essen formed a strike around claims of underpaid Kindergeld. They protested that while children present in West Germany were eligible for Kindergeld, those left behind in Turkey under the care of relatives did not qualify. ${ }^{50}$ To suggest that migrant workers required an outside influence to form an effective movement against their German employers discredits the migrant laborers' capacity for self-organization and labor activism; nevertheless, the fear of joint student-

${ }^{47}$ Quinn Slobodian, Foreign Front: Third World Politics in Sixties West Germany (Durham, NC: Duke University Press), 36.

${ }^{48}$ Dieter Süverkrüp, Studenten aus Entwicklungsländern an deutschen Hochschulen (Bonn: Studienstelle für Entwicklungsländer, 1963), 43 quoted in Slobodian, Foreign Front, 29.

${ }^{49}$ Slobodian, 33.

${ }^{50}$ Jennifer A. Miller, "Her Fight is Your Fight": 229. 
laborer activism was prophetic, in that it predicted the influence of university-educated leaders in the later Ford Strike of 1973.

\section{Turkish Workers in West German Society}

According to the 1975 edited volume of reports on the social, economic, and legal conditions of the Turkish guest worker in West Germany, there was no distinct "Turkish neighborhood" in Cologne, yet the degree to which Turks were segregated from the West German population was high. ${ }^{51}$ The report on living conditions of Turkish workers by John R. Clark indicated that the largest concentration of Turkish residences was in the immediate vicinity of factories because of the company-owned dormitories provided as housing to foreign workers. According to Clark, these dormitories could house "anywhere from several dozen to over 1,300 men in a single complex" and one-third of Cologne's Turkish population lived within seventeen of such complexes. ${ }^{52}$ The concentration of Turks in corporate-sponsored housing was not lost on the West German media. A satirical cartoon by critic Eckhard Tramsen first appeared in STERN magazine and was reprinted for use in the July 30, 1973 edition of Der Spiegel. The two figures in the illustration are described as employers surveying guest worker housing. The caption reads: "Here we can 'integrate' three Italians, eight Spaniards, or twelve Turks."

The significance of sociopolitical observations like Tramsen's editorial cartoon is that it establishes a hierarchal categorization of Gastarbeiter: while workers from more northernly countries were favored by German recruiters-like the few Brits, Americans,

\footnotetext{
${ }^{51}$ John R. Clark, "Residential Patterns and Social Integration of Turks in Cologne," in Manpower Mobility, 61.

${ }^{52}$ Ibid., 64-5.
} 
and French guest workers - the workers from southern Mediterranean countries were handled with less enthusiasm, and thus afforded inferior jobs and poor living quarters, with the most 'foreign' of these countries being Turkey. One may argue that this illustrates the lengths to which Turks would go to secure employment in West Germany, by accepting cramped and dilapidated housing and taking the most dangerous and lowpaying positions, yet this is a deceptive and contradictory analysis, when compared to the assessment of Turkish migrant workers at the beginning of Turkey's entry into a bilateral work agreement with the Republic. Instead, such sociopolitical commentary during the seventies illuminated the labor hierarchy of guest workers within the program by nationality, with Turkey occupying the lowest rung.

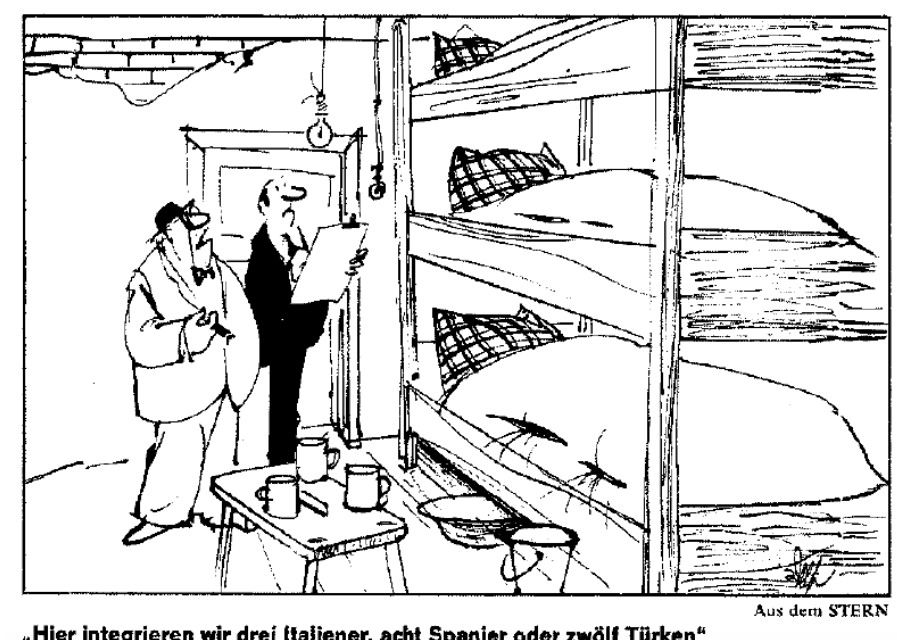

Figure 2. From Der Spiegel, July 30, 1973. Accessed at Der Spiegel Online Archive.

Though the West German public was critical of the Turks' frugal living conditions in factory dormitories, finding affordable private housing was difficult for migrant workers, especially when workers sent a portion of their wages back to their families in Turkey. By 1971, housing in Cologne was insufficient for the city's population and finding suitable housing was difficult for most Germans, though foreign 
workers had even harder time. A 1973 pamphlet entitled "Wir bleiben drin" ("We are staying here") provides testimony from one migrant worker who explained, "You can tell that the apartments were built to make money, not so people feel comfortable in them. The apartments are built in such a way that you can only watch television and then sleep, in order to be fit to go to work again the next day." 53 As Turkish laborers moved out of company barracks to integrated apartment buildings and complexes, they suddenly became more visible to the West German public, yet finding single-family apartments was a tremendous difficulty for many Turks, as landlords increased rents for migrant families or denied applications with 'foreign-sounding' names. Though housing existed in the villages surrounding large cities, the commute and increasing anti-Turkish sentiment limited workers to either insufficient company housing or often overpriced private apartments.

Landlords often pointed to cultural incompatibility as a basis for limiting or refusing migrants as tenants. Clark noted that "Another factor [was] the German landlord's preference not to rent to transient minorities or force regular tenants, many of whom sign five or even ten year leases, to share a stairway with them." 54 According to Clark, the stairway was a space where the most apparent cultural friction occurred when West Germans and Turks lived in the same complex. An apartment lease frequently included clauses devoted to the regulation of each tenant's section of the stairway-in terms of sanitation, prolonged, loud conversations in these shared spaces, and unattended children running up and down the stairs. For many, this was the flashpoint where German

53 “Wir bleiben drin," Flier, (Frankfurt: Häusserrat/AStA, 1973).

${ }^{54}$ Ibid., 68. 
norms and values clashed with Turkish ones. Insufficient housing was just one of the numerous pressures upon migrant workers, but with a lack of compensation for poor living conditions and heightened scrutiny upon the Turkish population in areas like Cologne assured the outbreak of a migrant, working-class movement.

\section{“Türkenstreik" at Ford, August 24-30, 1973}

The outbreak of the 1973 strike at Ford in Cologne was in direct response to a dismissal of three hundred Turkish workers who failed to return to work after the factorymandated holiday at the Ford Automobile Factory in Niehl, Cologne. Three weeks following the holiday at Ford, the absence rate among workers averaged at 28 percent, roughly twice the rate from previous years. ${ }^{55}$ According to the International Group of Marxists (Gruppe Internationale Marxisten) in the special Ford strike issue of their periodical Was tun, the slowing down of the final assembly line and overall production was directly related to the tardiness of workers returning from vacation. "In the final assembly in the Y-Hall, where the workers are almost exclusively Turks, the work after the company holiday began with a staff shortage of forty percent...into this powder keg, the management threw in the torch of three-hundred layoffs." 56 This reveals that the outrage of the workers (especially in final assembly) was not only linked to compassion

${ }^{55}$ Huwer, 'Gastarbeiter' im Streik, 235.

${ }^{56}$ While Was tun as a historical text carries clear biases - the promotion of a foreign 'proletariat' and similar revolutionary and Marxist language - it nevertheless captures the timeline of the strike and the conditions that lead to its outbreak. Texts like Huwer's " "Gastarbeiter' im Streik" confirm the facts and chronology presented in Was tun. See: "Der Streik bei Ford vom 24.8.-30.8.1973”, Was tun (Köln: GIM and Betriebszelle Ford der Gruppe Arbeiterkampf, 1973), 10. 
for their laid-off Turkish colleagues, but also alarm at the amount of additional work each of the workers were expected by management to take on.

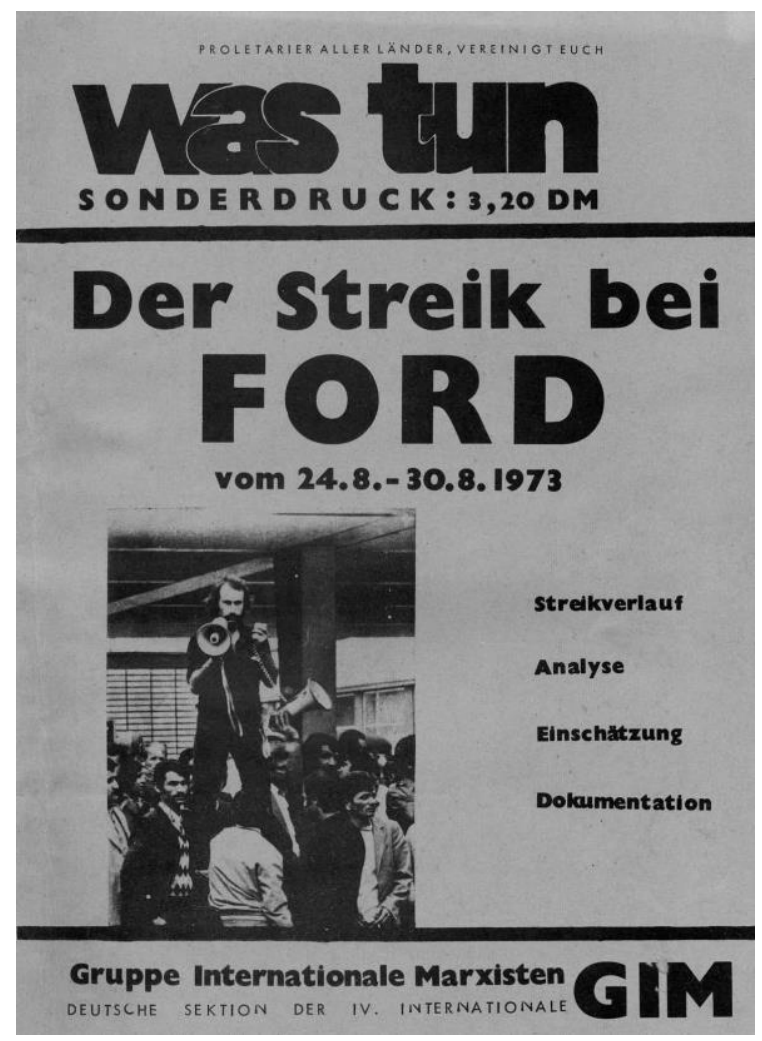

Figure 3. Cover of the Gruppe Internationale Marxisten (International Group of Marxists) periodical, Was tun (1973), featuring Baha Targün as the subject of the cover photo.

Since the factory management did not allow for new-hires to replace those dismissed, the pace and workload for each worker increased, specifically for the Turkish worker. ${ }^{57}$ Since factory halls like Y-Hall were made up of mostly Turkish workers, the terminations hit them the hardest. Most of the twelve hundred Turkish Ford workers at the time used their yearly vacation time to travel back to Turkey to see family, but to also put their affairs in order until they would return again the next year. Due to the vast

${ }^{57}$ Huwer, 'Gastarbeiter' im Streik, 235. 
distance Turkish workers travelled between West Germany and Turkey, Turkish Ford employees spent one-third of their permitted vacation in transit. ${ }^{58}$ Furthermore, vacation time became a common point of contention in West Germany for migrant workers and the idea of a different amount of vacation time for foreign workers drew the ire of some German coworkers. ${ }^{59}$

Beginning at around 3:30 pm on Friday, August 24, 1973 in the Y-Hall workshop, one thousand workers began a march towards the M-Building, where the workers' council and personnel administration were located. These workers were also joined by workers from the X-and FK-Hall, in protest of the layoffs, increased workload, and lack of compensation. ${ }^{60}$ While the workers' demands include the reversal of the recent layoffs, another demand is for a one-Deutschmark wage increase for all workers. It is due to this demand that many German workers join the strike and the overall "mood was good". 61 Three hours later, the workers' council meets with management to discuss the workers' terms, though the meeting ends unsuccessfully for both parties. Negotiations were set for the following morning and the striking workers subsequently march away from the factory and the management dismissed the entire workforce for the August 24 workday.

On Saturday, August 25, the strike seemed to have lost steam as the workday went on without incident. This was deceptive, however, since the assembly line did not operate on weekends; the only work that took place at Ford Köln on weekends was repair or improvements (for which workers were paid overtime). This overtime work, firmly

${ }^{58}$ Some sources indicate that the travel time could take up to two weeks, one half of the established vacation period. See: “TÜRKEN-STREIK: Faden gerissen," Der Spiegel (Nr. 37, 1973): 28.

${ }^{59}$ Miller, Turkish Guest Workers in Germany, 144.

60 "Der Streik bei Ford," Was tun, 10.

${ }^{61}$ Ibid. 
attested to by a former factory worker, was considered "a sacred thing", so the strike leadership chose to postpone the strike until the following Monday. ${ }^{62}$

Contrary to the appearance of calm at the factory, workers were assembling fliers and coordinating the efforts for the following workweek. According to Was tun, everyone who had a typewriter helped create pamphlets and brochures to pass out during the strike. These materials presented the key demands of the striking workers, namely one Deutschmark more per hour for all and the reversal of the 300 layoffs, but also six weeks vacation time (instead of the already established four weeks), back-pay for the strike days, and no actions or punishment taken against the workers who engaged in the strike. ${ }^{63}$ For the Turkish workers, the extra two weeks vacation would ease the pressure to return to Cologne before the end of the factory holiday. The final demand also posed an increased benefit to the Turkish worker, since they did not receive as much representation and protection as employees compared to their German counterparts, ensuring that no retaliation would follow Turkish workers who had participated in the strike.

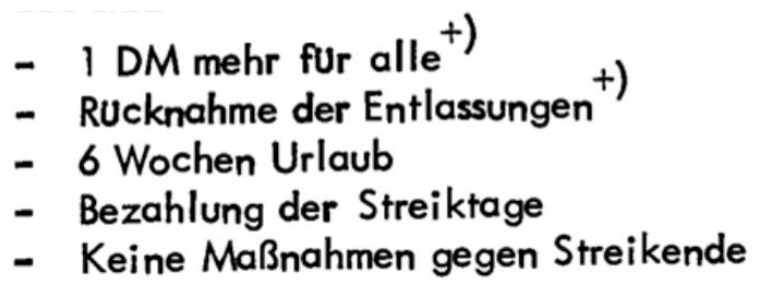

\section{$+)_{\text {Hauptfor der ungen }}$}

Figure 4. The list of demands from the 1973 Ford strike from "Der Streik bei Ford vom 24.8.-30.8.1973" in Was tun, 1973. The "+)" symbol indicates the priority demands on the list, namely, one Deutschmark more for all employees and the rehiring of the three-hundred terminated Turkish migrant laborers. Not included is the later demand that the speed of the end-assembly conveyer belt be decreased.

${ }^{62}$ Huwer, “"Gastarbeiter' im Streik,” 237.

63 "Der Streik bei Ford," Was tun, 11. 
When it appeared as though Ford management would not continue with negotiations on Monday morning as promised, a group of workers emerged as the leadership of the strike from that moment forward, which some scholars indicate as the turning point of the Ford strike from a unified effort by migrant and German workers to the "Türkenstreik" in historical recollection. Due to the workers' council's faltering and their failure to rekindle negotiations with management, they lost the confidence of the striking workers - German workers dropped out of the strike, Turkish workers looked to the formation of a primarily migrant strike leadership to continue the movement. At the suggestion of a piston-grinder named Baha Targün, a strike committee was formed as the new leading body of the strike. The new leadership was made up of nine Turkish workers (including Targün), two Italian workers, a communist and an "anarcho-syndicalist". ${ }^{64}$ Was tun indicates that there was also a Yugoslavian worker on the committee, as well as two Germans. ${ }^{65}$

Among the Turkish migrants selected to the new strike leadership, Targün became well known as the voice of the strike because of his expert grasp of the German language and his level of university education. ${ }^{66}$ The thirty-year-old Targün did not have the typical guest worker background: Targün came to West Germany for the first time in 1969 to live with his sister in Cologne where he enrolled as a sociology student at the university. Prior to his work at Ford, Targün had worked as a translator and a bank teller, but in an interview with Stern, he explained his motivation for taking a job at Ford: "I

${ }^{64}$ Huwer, 238. Huwer does not indicate if the communist in question is Targün, as Targün was a Communist Party member, nor if the communist and the 'anarcho-syndicalist' are the same individual.

65 "Der Streik bei Ford," Was tun, 11.

${ }^{66}$ Foerster, 257. 
wanted to help my countrymen. I wanted to study their circumstances and publish a book about it in Turkey. That's why I went to Ford as a worker."67 As a member of the Communist Party of Germany (KPD), Targün sought to experience the classist struggle by exposing himself to the typical experience of the Turkish guest worker. In the many photographs taken during the strike, Targün can often be spotted listing the strike's demands over loudspeaker and engaging the swell of workers pressed against the Ford Cologne Factory gates; though arguably not the leader of the strike, Targün's presence left an indelible mark upon its public reception.

The strike ended in a violent clash between the striking Ford workers and police, aided by frustrated 'willing-to-work' (arbeitswillige) Ford employees. Four days after the strike began, on August 30, "heavy turmoil" developed between strikers and disgruntled German Ford employees who called for police to break the strike. ${ }^{68}$ As Der Spiegel recounts, five hundred German Ford workers stood before the factory's G-Hall and yelled, "We will work! We will have police protection!", as well as "Strike the rats [the Turkish workers] dead!"69 While police dispersed the crowd, the "ringleaders" of the strike were identified, including Targün, and arrested. ${ }^{70}$ As Der Spiegel later heralded, “[t]he 'Turks' Strike' at Ford ended with a German victory..."71 After his arrest and overnight in jail, Targün was taken underground. In an interview with Stern magazine,

${ }^{67}$ The book Targün mentioned ultimately was not published. "Die Konjunktur-Kulis proben den Aufstand," Stern (Nr. 37/1973): 159.

68 "Schwere Tumulte bei Ford und Rheinstahl!" BILD-Zeitung (202/35): 1.

69 "Die Konjunktur-Kulis proben die Aufstand," 167; “"Wie lange sollen wir uns das gefallen lassen?!' Zur Geschichte migrantischer Kämpfe in Deutschland: Der 'Fordstreik', 1973," Lotta (Nr. 52, Summer 2013): 61.

${ }^{70}$ Foerster, 260.

71 “TÜRKEN-STREIK: Faden gerissen,” der Spiegel (Nr. 37/1973): 28. 
Targün was described as having a bruised left eye and injuries over his entire body, sustained from the clash with both "willing-to-work" German coworkers and the police. ${ }^{72}$

\section{Media Representations: "Türkenterror bei Ford" leads to "Türken Raus"!}

The emphasis on the racial aspects of the strike and employment of phrases like 'Turks' Strike' or 'Turk-Terror', as Birke explains, had 'little to do with the course of the strike and more to do with an attempt to maintain the boundaries of the labor market."73 In order to maintain the tenuous partnership as it had existed for a decade in the original bilateral agreement, the rhetoric surrounding the strike focused on racialized and nationalized undertones, rather than the conditions of the workers in the end-assembly as a whole; one such word repeatedly employed was 'Kulis' (Coolies), a word describing indentured laborers or slaves with implications of British rule over Indian subjects. ${ }^{74}$ Another term, more akin to a racial slur than a labor-related slur, 'Kanak,' which opponents of the Ford strike also used to refer to Turkish migrants. ${ }^{75}$ Die Stern recorded a German coworker recorded as stating that, in reference to the violent end of the strike, "we will not yet allow these 'Kanaken' run our workplace into the ground."76 The implementation of such language further reinforced (on both a conscious and unconscious level) the lack of rights owed to migrant workers in metalworking factories like Ford and insinuated the piteous amount of weight their arguments bore, according to

\footnotetext{
72 “Die Konjunktur-Kulis proben den Aufstand," 157.

${ }^{73}$ Birke, 274.

${ }^{74}$ See: "Die Konjunktur-Kulis proben den Aufstand,", 156; "Faden gerissen,", 28..."Nur wenige Stunden der Solidarisierung mit deutschen Arbeitskollegen hatten den Ford-Türken, 38 Prozent der Gesamtbelegschaft und 90 Prozent der Fließband-Kulis..."

75 The term comes from the German colonial lexicon, an indigenous term used to describe

76 "Die Konjunktur-Kulis proben den Aufstand," 157.
} Polynesian subjects. 
the German public. Similarly, the emphasis on the religious difference of the majority of workers on strike, assumed to be Muslim, further isolated the strike from the public's sympathy. Caricatures like the illustration drawn by Klaus Pielert in a late-August handbill portrayed the strike leadership, like Targün, as zealous Muslim leaders, shouting demands over a crowd of witless workers from a minaret.

Figure 5: Caricature c Ramadan, we rumr language and gramn religious evaluation . Sour On Augus 1 newspaper, an ope communists stealtl jackets." ${ }^{, 77}$ BILD h and this claim hin€̨

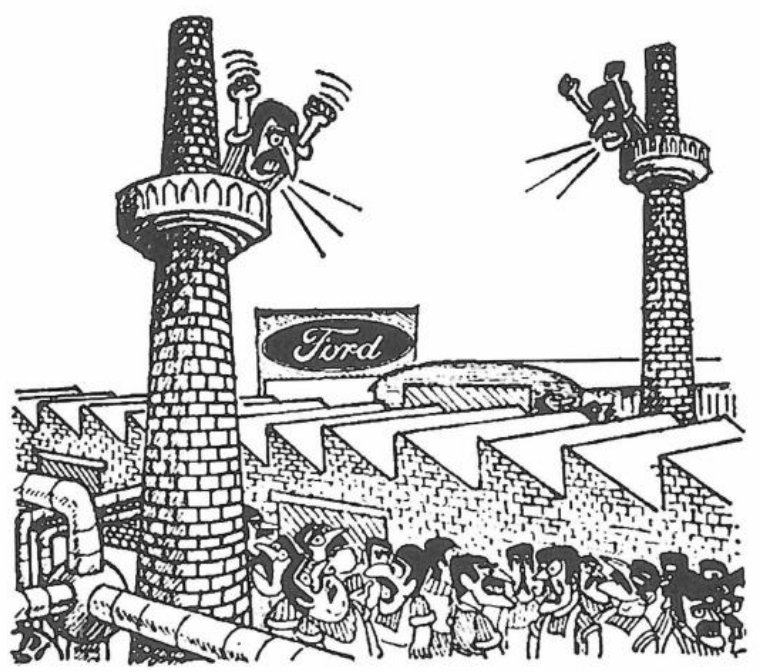

vir Remmidemmi" (No rrkers' poor German ‘), but also presents a and the call to prayer. iphlet.

rike, the BILD

that "six to eight

vearing camo

vith racist ideology

between West

Germany and communist-allied nations, including the German Democratic Republic.

This fear also informed the reception of the strike's leading speaker, Baha Targün:

though Targün was university educated and possessed a fluent grasp of the German

${ }^{77}$ Die BILD-Zeitung $(29,8.1973)$. 
language, his unashamed communist party affiliation lead to the media describing him as a radical. While Targün was a radical communist, BILD conflated his political affiliation with the labor movement.

In addition to racialized and politicalized language, the media reinforced the migrant labor movements of 1973, including the Ford strike, as violent. On September 3, 1973, the cover of Der Spiegel featured a group of marching Turkish men, hands raised high, chanting the slogans of their strike, including "eine Mark mehr!" and "sechs Wochen Urlaub!". The headline read "Wildcat Strikes: Wage Politics on One's Own," with a seemingly positive meaning, but the idiom "auf eigene Faust" employed by Der Spiegel alluded to an undercurrent. Though this saying means "on one's own," it literally means "by one's own fist." Targün, for his influence and role as speaker for the strike, earned the label 'agitator' or 'Turks' agitator' in later media accounts of the Ford strike. ${ }^{78}$ Other anxious headlines read "Are the Guest Workers Taking Power? For the First Time They Are Aware of Their Strength", deeming the strike nothing short of a "Türkenterror."79

78 “Faden gerissen," der Spiegel (1973): 31.

79 "Übernehmen Gastarbeiter die Macht? Zum ersten Mal sind sie sich ihrer Stärke bewusst,“ Kölner Express (29.8.1973). 


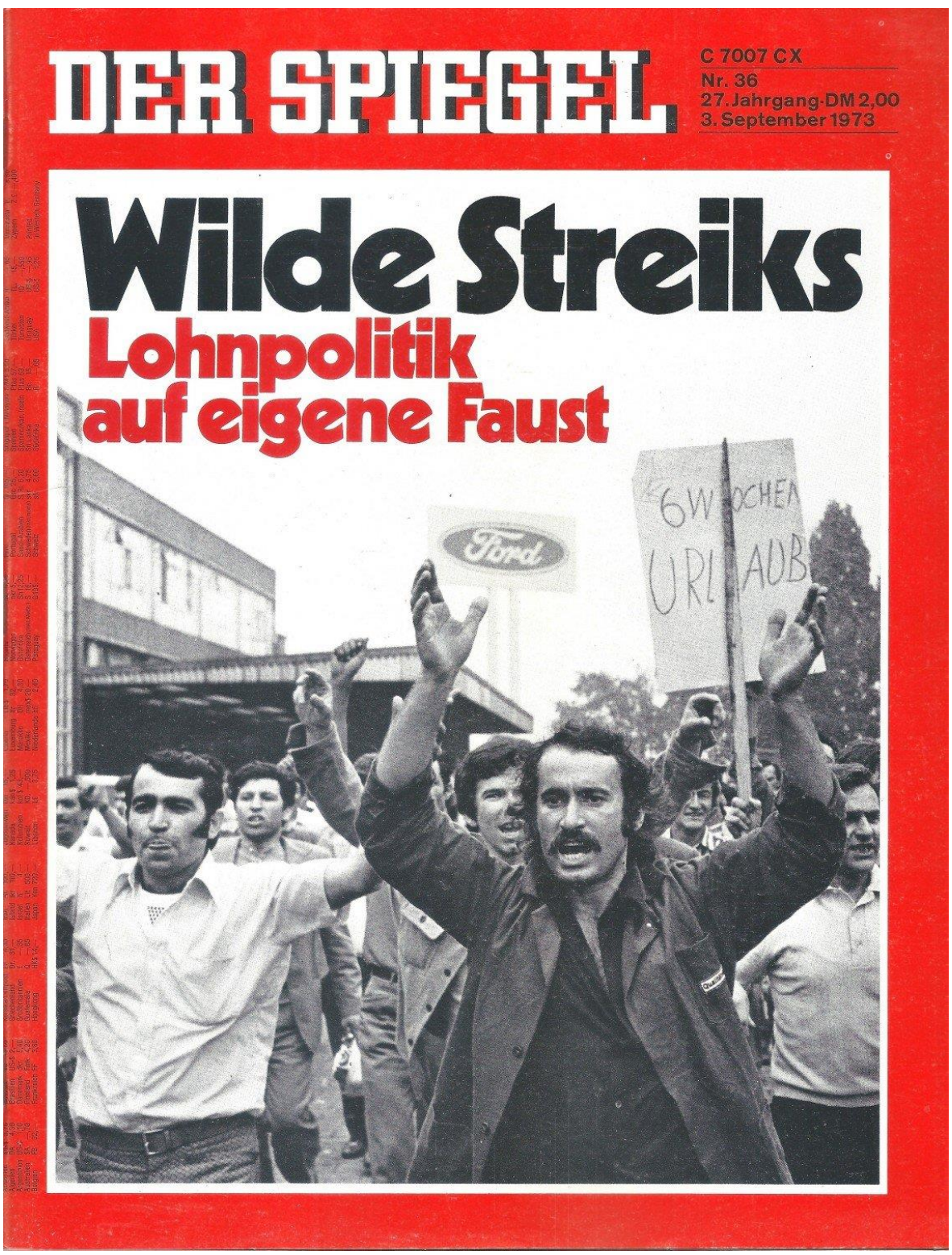

Figure 6. The September 3, 1973 cover of Der Spiegel. The main speaker for the striking workers, Baha Targün, marches in the very foreground of the image.

\section{Conclusion}

Fritz Franz' chapter in the 1975 volume Manpower Mobility Across Cultural Boundaries: Social, Economic, and Legal Aspects: The Case of Turkey and West Germany provides a prophetic assessment of the consequences of legal inequities facing 
the foreign laborer: "If the Federal Republic does not wish to exclude migrants from the domestic labor market, it will of necessity have to come to grips with integration. As history teaches, a lack of rights produces social tensions and conceals explosive dangers. ${ }^{80}$ Due to unequal pay between migrant and German workers, inferior company dormitories and discriminatory private housing practices, and the overall legal insecurity of the migrant worker in West German society, migrant protests like the 1973 strike at the Ford Cologne Niehl automobile factory were assured. As the strikes of 1973 fell upon the cusp of the guest worker recruitment ban of November the same year, the image of the highly-publicized Ford strike impressed itself upon the collective West German mind and the argument against later integration of migrant workers was informed by the strike's violent ending.

The failure of the Ford strike lay within the adversity against it. Since the migrant workers did not have the support of the workers' council, the approval of a trade union (due to their status as migrant laborers), nor the support of the city of Cologne at large, their demands and calls for improved working conditions on the end-assembly line fell on deaf ears. Yet, though the strike failed, the workers involved did not completely resign themselves to this fate. Turkish Ford employees generated documents after the 1973 Ford Strike, like a poster entitled What You Should Know Before Buying a Car (for example, FORD). ${ }^{81}$ This poster features nine red and white photographs from the strike, including images of a march, Baha Targün speaking to striking workers through a megaphone, newspaper clippings declaring "Heavy Tumult at Ford", and the eventual clash between

\footnotetext{
${ }^{80}$ Franz, 60.

${ }^{81}$ Was Sie vor dem Kauf eines Autos wissen sollten (z.B. FORD), 1973. Poster. DOMiD Object no. 6152.
} 
police and migrant workers that ended the strike. The creators of this poster handprinted captions over each photograph, detailing how purchasing a automobile through Ford allowed such work conditions to continue. Another migrant-generated document from the following year called on Turkish Ford employees (as the document is exclusively written in Turkish) to protest differential treatment of former guest workers at Ford at a rally set for July $9,1974 .{ }^{82}$ The call to action concludes, "We can't beat injustices as long as we are quiet. Always resist all unfairness, let us resist!'. It is apparent through the continuing efforts of Turkish migrant workers that the failure of the 1973 Ford Strike did not mark the end of their labor activism at the Cologne Ford Factory, nor did it squash the aspirations of the strike's former leadership, Baha Targün.. Targün wrote from his prison cell on September 22, 1975, calling on his fellow communist party members to keep up the publicity regarding the political prisoners of the strike two years prior:

It has long been known that in the prisons of the German imperialist that they terrorize political prisoners through isolation. It is very common for the isolated prisoners to receive a visitation and newspaper ban at the same time. Now the judicial authorities are continuing further and are plainly attempting to steal away the democratic rights of the prisoners, as well. What I have just reported to you all are my own experiences. All that is yet to see we cannot know, but we can easily imagine. ${ }^{83}$

The crackdown on the strike served to silence the strike and its leadership and the failure of the strike informed later gendered integration rhetoric, it had not killed the spirit of the Turkish migrant labor activist.

${ }^{82}$ HAYM'LERE YAPILAN ZAMLARI PROTESTO EDELIM!, 1974. Poster. DOMiD Object no. 8902.

${ }^{83}$ Baha Targün, Baha T. aus der Justizvollzugsanstalt Köln-Ossendorf an politische Genossen, 22.9.1975. Brief. DOMiD, E 0638,004. 


\section{Chapter 2}

The 'Woman's Wage': The Pierburg Strike, August 13, 1973

From inception of the 'guest worker' program to the Anwerbestopp, the dominating image of the migrant worker in West German society was young, single, and 
male - much like the well-circulated image of Rodrigues or even the lean, mustachioed Baha Targün leading fellow protesters to the factory gates. After the Ford Strike, this male migrant image shaped the way in which migrant women (many of whom were guest workers) were perceived by West Germans. The silencing of the economic contribution of foreign women in West Germany represented an evolution in the way in which society viewed their presence; German historian Monika Mattes succinctly details this change in recollection, stating that non-German women were considered by West Germans as "the passive tag-alongs of their economically active husbands. ${ }^{" 84}$ For Turkish woman migrants in particular, this economic devaluation also represented a change in which West Germans perceived their 'foreign' presence in society. Amid questions of integration in the post-Anwerbestopp Federal Republic, various German groups utilized the 'treatment' of Muslim (Turkish) woman as the fundamental gauge of the Turks' inability to be incorporated into German society, with Turkish as being too controlled and Turkish men as harsh patriarchs. Yet, during the over one hundred-forty migrant labor strikes of 1973, migrant woman workers utilized gender as a means to forward one strike's demands. It is significant to note that while gendered language served to benefit migrant laborers prior to the recruitment ban, gendered rhetoric in the later integration debate proved detrimental to the Turkish woman migrant. The benefit of a gender-based labor movement for migrant women is that it highlighted a commonality between West

${ }^{84}$ Monika Mattes, "Gastarbeiterinnen” in der Bundesrepublik: Anwerbepolitik, Migration und Geschlecht in den 50er bis 70er Jahren (Frankfurt: Campus Verlag, 2005), 10. For an international example of patriarchal trade union policies and women, see: Michelle K. Rhoades, "Sexual Labor and the Transnational Sphere," Journal of Women's History 27, No. 3, (Fall 2015): 187-193; Yevette Richards, "Labor's Gendered Misstep: The Women's Committee and African Women Workers,1957-1968," The International Journal of African Historical Studies 44, no. 3 (2011): 415-442. 
German women and migrant workers. However, after the recruitment ban, the gender of migrant women underlined differences rather than commonalities, as political proponents of a forced Rückkehr (return trip) pointed to assumed condition of Muslim Turkish women in Turkish patriarchal family units.

As mentioned in the introduction, Turks represented the largest group of migrant workers by nationality in $1973 .{ }^{85} \mathrm{~A}$ considerable percentage of the Turkish migrant workforce were women, but family reunification in 1974 aided in the misconception in West German society that Turkish women were cloistered, veiled, and oppressed ${ }^{86}$ This trope was further reinforced in the late-seventies and early-eighties by West German feminist literature that claimed to grant the reader an exclusive peek into the hidden life of helpless, oppressed Muslim-Turkish bride, a genre that has persisted into the twentieth century. ${ }^{87}$ Conservative politicians and West German feminists alike pointed to this blanket portrayal of Turkish women as the litmus test for the inability of Turks to integrate successfully into German society. The presence and economic viability of the once "Turkish woman migrant worker" was reduced to "Muslim wives and daughters" in the late seventies and eighties. The end of the exponential economic growth of the Wirtschaftswunder marked a shift in the West German perspective towards migrant workers, particularly Turkish women. While the Turkish woman migrant worker was

${ }^{85}$ Twenty-three percent, according to H. Korte and A. Schmidt, Migration und ihre sozialen Folgen (Göttigen: Vandenhoeck und Ruprecht, 1983), 12f; cited as a table in Herbert, $A$ History of Foreign Labor in Germany, 203.

${ }^{86}$ The term 'Gastarbeiter' itself is deceptive: in the German language, this word means "guest worker", but it is a distinctly male-gendered word. Unless the female-gendered pronoun "Gastarbeiterin" was used in print or by word-of-mouth, the audience would automatically assume that the guest worker in question was male.

${ }^{87}$ Approximately 24.4 percent of Turkish migrant workers in 1973, according to Mattes, "Gastarbeiterinnen" in der Bundesrepublik, 187. Chin notes that in 1973, approximately thirty percent of the entire migrant workforce was female (Chin, The Guestworker Question, 40). 
viewed as a boon to the workforce and the ideal replacement for West German in traditionally 'female' industries, she was societally recast as an economic drain and societal recluse - unable to integrate and controlled by a foreign patriarchal family structure. This shift in perception of Turkish women not only devalued the woman migrant as a former guest worker and active economic participant in West Germany, but also served as a way to further emphasize cultural difference as an explanation for the expulsion of former Turkish guest workers after the recruitment ban.

Mattes notes that an emphasis on the recruitment of foreign women emerged during the mid-sixties, concurrent to a period when ethnic German women were called on by the West German government to 'return home' in the face of the low national birthrate. ${ }^{88}$ Though women were continually referred to as the German workforce's "silent reserve" of workers, BRD officials released a report advocating for women to either leave the workforce or opt for a part-time job. ${ }^{89}$ The December 5, 1957 issue of Die Zeit presented the findings from this report and discussed the issues associated with this campaign: "It is clear that neither employers are interested in hiring exclusively part-time workers and nor is there a great interest among women to go from full-time work to parttime." ${ }^{90}$ By 1960, however, the Ministry of Labor instructed the Press and Information Office to radio broadcast information on part-time work, to familiarize women with the concept and the "insurance and tax implications" that accompanied part-time work. ${ }^{91}$

\footnotetext{
${ }^{88}$ Mattes, "Gastarbeiterinnen" in der Bundesrepublik: Anwerbepolitik, Migration und Geschlecht in den 50er bis 70er Jahren, 10-12.

${ }^{89}$ See Anneliese Fuest, et al, Möglichkeit und Zweckmäßigkeit der Einrichtung von Teilzeitarbeit für Frauen in verschiedenen Berufen. Gutachten des Forschungsinstitut für Sozialund Verwaltungswissenschaften der Universität Köln, with a forward from Gerhard Weisser, MS Köln, 1954 (1956).

90 "Halbtagsarbeit—wissenschaftlich erforscht," Die Zeit, December 5, 1957.

${ }^{91}$ Christine van Oetzen, Teilzeitarbeit und die Lust am Zuverdienen: 121-2.
} 
While the article recognized the disinterest of ethnic German women to become 'halfday' workers, there is mention of the implementation of tax deductions for corporations who employ part-time workers, foreshadowing the depreciation of the individual wage versus the "family wage." 92 The West German state instead looked to another 'silent reserve' to develop 'women's industries': woman migrant laborers.

Conservative politicians and West German feminists alike pointed to this blanket portrayal of Turkish women as the litmus test for the inability of Turks to integrate successfully into German society. Thus, the presence and economic viability of the once "Turkish woman migrant worker" was reduced to "Muslim wives and daughters" in the late seventies and eighties. The end of the exponential economic growth of the Wirtschaftswunder (economic wonder) marked a shift in the West German perspective towards migrant workers, particularly Turkish women: while the Turkish woman migrant worker was viewed as a boon to the workforce and the ideal replacement for West German in traditionally 'female' industries, she was societally recast as an economic drain and societal recluse - unable to integrate and controlled by a foreign patriarchal family structure. This paper examines this dramatic shift in perspective and challenges existing interpretations of the existence of Turkish women in West German society as more complex and intersectional than previously thought by introducing the women of the Alfred Pierburg strike in 1973 as tangible examples of not only the woman migrant worker's agency, but also the employment of gender as a means to further conditions for multi-national migrant worker conditions.

\footnotetext{
${ }^{92}$ Margitta Mätzke and Ilona Ostner, "The Role of Old Ideas in the New German Family Policy Agenda," German Policy Studies 6, no. 3 (2010): 138.
} 


\section{Historiography}

Considering that the guest worker program began less than sixty years ago, the historiography of postwar labor migration in West Germany is still relatively young. The transnational nature of labor migration history also contributes to a lack of scholarship on the Gastarbeiter program, as primary sources (and the former workers themselves) exist between multiple states. The status of the migrant worker as a liminal figure in West German society also delayed serious inquiry into their contribution to German history. In the past fifteen years, a small number of German, Turkish, and American have begun to address the economic, social, and political import of the GastarbeiterIn, instead of interpreting the presence of the migrant worker as auxiliary to (West) German history.

In terms of German secondary sources, there are three main scholars in the field of German migrant labor history: Monika Mattes, Karen Schönwälder, and Karin Hunn. Monika Mattes' “Gastarbeiterinnen” in der Bundesrepublik: Anwerbepolitik, Migration und Geschlecht in den 50er bis 70 er Jahren ${ }^{93}$ provides an expansive analysis of the presence of woman migrant laborers in West Germany and the challenges to that presence by West German law and public perception. Mattes' text provides a welldeveloped overview of the economic and social landscape woman migrant workers (especially Turks) experienced, from the specialized recruitment of women in laborexporting countries to the uncertainty of integration after the Anwerbestopp. Mattes' work suggests what factors led to the devaluation of the Gastarbeiterin in the West

${ }^{93}$ Monika Mattes. "Gastarbeiterinnen” in der Bundesrepublik: Anwerbepolitik, Migration und Geschlecht in den 50er bis 70er Jahren (Frankfurt: Campus Verlag, 2005). 
German economy and society and concisely points to the relationship between the return of West German women to the home and the introduction of foreign women workers to fill that vacancy.

Schönwälder's influential Einwanderung und ethnische Pluralität: Politische Entscheidungen und öffentliche Debatten in Grossbritannien und der Bundesrepublik von den 1950er bis zu den 1970er Jahren explores immigration in Germany as a recurring topic of public and political debate. ${ }^{94}$ Using British 'colonial immigrants' as a comparison to the 'guest worker' program, Schönwälder notes the ethnic and racial implications of migrant labor in Europe as a sort of neocolonialism. Hunn's "Nächstes Jahr kehren wir zurück...": Die Geschichte der türkischen "Gastarbeiter" in der Bundesrepublik analyzes the assumption by West Germans in public debate that the continued presence of Turks in Germany constituted a sort of "creeping immigration process", meaning that Turks extended their stay in the Federal Republic of Germany in order to establish citizenship. ${ }^{95}$ Hunn argues, however, that many Turkish migrant laborers did not plan to stay for long, but could not meet their savings goals and therefore continued working. These three scholars provide clarification into the complex and multifaceted guest worker phenomenon during the late twentieth century.

Many scholars of migration history consider Nermin Abadan-Unat to be the foremost expert on the post-World War II migration of Turks into Europe, owing to her

${ }^{94}$ Karen Schönwälder, Einwanderung und ethnische Pluralität: Politische Entscheidungen und öffentliche Debatten in Grossbritannien und der Bundesrepublik von den 1950er bis zu den 1970er Jahren (Essen: Klartext Verlag, 2001).

${ }^{95}$ Karin Hunn, „Nächstes Jahr kehren wir zurück... “: Die Geschichte der türkischen ,Gastarbeiter' in der Bundesrepublik. Göttingen: Wallstein Verlag, 2005. 
recruitment by the Turkish government to survey the program. ${ }^{96}$ Abadan-Unat's Turks in Europe: From Guest Worker to Transnational Citizen demonstrative of this claim. ${ }^{97}$

While the text focuses on Turks in the entire European continent, eighty percent of the population lives in Germany; therefore the text's primary geographic focus is still upon (West) Germany. What is notable about Abadan-Unat's work is that she does not focus solely upon the conflict between Turks and Germans. Turks in Europe presents and analyzes the conflicts within the Turkish communities in Europe, such as the divides along generational, religious, and cultural demarcations. ${ }^{98}$ Abadan-Unat also describes the conflict between those who left for Europe and came back, those who did not, and those who stayed in Turkey throughout the entirety of the Gastarbeiter program. AbadanUnat's Turks in Europe is indispensable for its alternative framework by which to view the phenomenon of labor importing and exporting after the Second World War; instead of viewing the program as an auxiliary to the history of Germany, Abadan-Unat analyzes this event from a Turkish and thematic perspective.

Jennifer Miller is the foremost American authority on migrant labor strikes in West Germany and the complex existence of female guest workers in the West German society and economy. Since her dissertation has yet to be published in book format, Miller's article 'Her Fight is Your Fight: 'Guest Worker' Labor Activism in the Early 1970s West Germany" is the principal scholarly text related to the August 1973 Pierburg

${ }^{96}$ It must be noted, however, that Abadan-Unat is not a historian, but a sociologist. Yet, Abadan-Unat's work is crucial to the further development of this field of research.

${ }^{97}$ Abadan-Unat, Nermin. Turks in Europe: From 'guest worker' to Transnational Citizen. Translated by Caterine Campion (New York: Berghahn Books, 2011).

${ }^{98}$ In the case of the image of the Turkish-Muslim woman in West German society, Abadan-Unat argues that a growing feminist movement in Turkey in the mid to late-seventies demonstrates one such internal conflict. 
strike, by which woman migrant workers successfully abolished a 'women's' wage bracket at the Alfred Pierburg automobile parts factory in Neuss, Germany. ${ }^{99}$ Miller argues that by participating in labor strikes, migrant woman workers (mainly Greeks, Turks, Yugoslavs, Italians, and Spaniards) demonstrated their "political consciousness". ${ }^{100}$ Miller argues that a strike is not a solution to resolve temporary issues or complaints: by engaging in labor strikes, migrant laborers demonstrated that they expected permanent, long-term results. Specifically in relation to the August 1973 strike at Pierburg Neuss, Miller asserts that labor activism enabled the woman migrant worker to not only assert her permanency in the West German work force, but also affirm her claim to an intersectional identity in society.

Rita Chin's research and analysis in The Guest Worker Question in Germany is a principal work that lends insight into many different spheres of experience for Turkish guest workers. ${ }^{101}$ While the text suggests that the text provides a detailed explanation to the 'guest worker question' as a whole, this work instead focuses on the relationship between the voices of West German society, politicians, and intellectuals and that of Turkish intellectual opposition during the latter half of the twentieth century. Chin's text is effective, however, in clearly identifying the major shifts in the 'guest worker question'-from the initial stage of the program where the idea that migrant workers would end up staying in West Germany seemed unthinkable, to the development of integration policy, to the creation of the trope of the oppressed Turkish-Muslim woman,

\footnotetext{
${ }^{99}$ Jennifer Miller, Turkish Guest Workers in Germany: Hidden Lives and Contested Borders, 1960s to 1980s. (Toronto: University of Toronto Press, 2018).

${ }^{100}$ Jennifer Miller, “Her Fight is Your Fight: 'Guest Worker' Labor Activism in the Early 1970s West Germany" International Labor and Working-Class History no. 84 (Fall 2013): 227.

${ }^{101}$ Rita Chin, The Guest Worker Question in Postwar Germany. (New York: Cambridge University Press, 2007).
} 
to backlash in the early eighties, towards the development of Multikulti (multiculturalism) as national political policy.

Chin's The Guest Worker Question includes a chapter wholly devoted to the public discourse over gender and the degree to which the Turkish migrant could be integrated into German society. This chapter reveals the way in which gender was utilized as a rhetorical means to measure the "incommensurable cultural difference" between ethnic Germans and Turkish migrants seeking German citizenship. ${ }^{102}$ In this text, Chin points to the election of Helmut Kohl in the early eighties as the harbinger of heightened backlash against integration and Ausländerpolitik and the rise of the Right in Germany and in Europe as a whole. ${ }^{103}$ From Chin's analysis, this point in (West) German history further made the terms 'Muslim' and 'Turk' interchangeable in public discourse. Chin's “Turkish Women, West German Feminists, and the Gendered Discourse on Muslim Cultural Difference” (2010) is a further analysis of the Turkish/Muslim difference the public discourse upon migrant integration hinged.

Finding secondary literature on the history of activism within the labor migration program in West Germany proves more difficult than finding information on the 'guest worker' program. A key article in the understanding of the migrant labor strike phenomena is Simon Goeke, Victoria Harris, Barbara Könczöl, and David Motadel's "The Multinational Working Class? Political Activism and Labour Migration in West Germany during the 1960s and 1970s" (2014). This article deftly assesses that the

${ }^{102}$ Chin, The Guest Worker Question in Postwar Germany, 141.

${ }^{103}$ Foreigner policy here refers specifically to the development of integration policies that would lead towards citizenship for many guest workers, such as family reunification in West Germany. 
historiography of labor migration in (West) Germany has neglected the political and social movements of (and support for) guest workers. "The Multinational Working Class?" also explores the impact the policy of German trade unions had upon the labor market and how they reinforced preferential employment of ethnic Germans. This work is essential in repositioning the migrant laborer as an active participant in West German society, not just a temporary, liminal presence. These younger authors argue that the migrant worker is not only prevalent throughout to the history of the Federal Republic of Germany, but is instead emblematic of the former West German state. ${ }^{104}$

\section{The Gastarbeiterin on Strike: The Active Turkish Woman Migrant, August 13, 1973}

The efforts of the state to encourage family size and limit the number hours ethnic West German women worked per day left a considerable need for laborers in traditionally 'female' industries. According to Nermin Abadan-Unat in Turks in Europe: From 'guest worker' to Transnational Citizen, Turkish women entered the guest worker program largely due to influence by their husbands. Abadan-Unat reasons that,

Given the fact that during this period over 1 million Turks were registered for work permits and contracts at the Turkish Labor and Employment Office, the chances for men at the bottom of the list to get a contract were low. However, when it became evident that women were in demand and, if they were recruited, employed women could, after a certain period of time, claim for family reunion, a silent but relevant change in the minds of average men took place. ${ }^{105}$

${ }^{104}$ Simon Goeke, et al, "The Multinational Working Class? Political Activism and Labour Migration in West Germany During the 1960s and 1970s." Journal of Contemporary History 49, no. 1 (2014): 161.

${ }^{105}$ Nermin Abadan-Unat, Turks in Europe: From 'guest worker' to Transnational Citizen (New York: Berghahn, 2011), 89. 
While Abadan-Unat's assertion is not wholly indicative of the experience of all Turkish guest workers' recruitment, but the possibility of this form of 'chain migration' manipulation by Turkish husbands - in the minds of West Germans perpetuated the societal trope of the controlled Turkish woman.

In contrast to the trope of the oppressed Turkish bride, the woman migrant workers at the Alfred Pierburg factory in Neuss demonstrated that they were not only equal to their male counterparts, but also possessed the ability to organize and mobilize a diverse group of three thousand workers (including women, men, migrant workers, ethnic Germans, and some factory officials) in order to abolish a sexist wage group: and succeeded. ${ }^{106}$ Though the strike at Pierburg in Neuss only lasted for a week, the wildcat strike highlights the intersectional history of the Gastarbeiterinnen - intersecting the politics, social issues, economy, gender, and legal issues of the time. The 1973 Pierburg strike is an episode in West German history that suggests a willful 'forgetting' in German society and politics, indicating that this event was quickly disremembered due to family reunification in 1974 and the Reportage on the Turkish woman in Germany as a popular trade book genre. The importance of the Pierburg Strike in German history is that it reintroduces these economically active women to the literature of the 'guest worker' program.

Though IG Metall and the West German media labeled the August 1973 Pierburg Strike as a wildcat strike — spontaneous and unsanctioned by the workers' council and the trade union - the women at Pierburg circulated fliers and information as early as August

${ }^{106}$ While the woman migrant workers at Pierburg did not receive the one DM per hour they demanded, but they managed to force a 53-65 Pfennige (cent) hourly increase, and they effectively abolished the 'woman-only' wage bracket. 
7, 1973. These documents were written in German, Serbo-Croatian Spanish, Italian, Turkish, Greek, in an effort to ensure that every worker at the factory would receive the call to strike. ${ }^{107}$ The August 7, 1973 flier disseminated among workers declared that "3,000 STRIKERS can be the only answer!" Another document shows a hand-drawn diagram of the strike's proposed Leitungskomitee (strike leadership committee), detailing who would speak to the press and who from each factory station would lead and the number of individuals under their guidance. ${ }^{108}$ With these documents in mind, the classification of the Pierburg Strike as a wildcat strike was, in short, due to the migrant workers' lack of representation by the trade union, not spontaneity. Since IG Metall did not permit the strike, the Niederlegung (refusal) of work by the women on the assembly line was deemed by the union as illegal.

On August 13, 1973, as the 6:00 AM shift were assembling in front of the factory gate, around twenty factory workers once again circulated fliers within the crowd, encouraging their coworkers to join them in abolishing Leichtlohngruppe II and striking for a one Mark per hour increase in wage for the female factory workers. ${ }^{109}$ The organizers of the strike were primarily Greek, Turkish, and Yugoslavian, but as the flyers passed hand to hand outside of the factory, the support of German coworkers-from men and women alike—was evident. By 7:00 AM, Alfred Pierburg management made an emergency call to police to disperse the crowd gathered in front of the factory gate.

${ }^{107}$ Einsatz Aller Kräfte, August 7, 1973, Flier. DOMiD, E 0778,0028.

${ }^{108}$ Strategieplan der Streikenden, 1973, Document. DOMiD, E 0727,0001 a-b.

${ }^{109}$ Dieter Braeg, "Wilder Streik—das ist Revolution": Der Streik der Arbeiterinnen bei Pierburg in Neuss, 1973 (Berlin: Der Buchmacherei, 2012): 33. 
Based on the footage from Edith Schmidt, David Wittenberg, and Raimund Kirchweger's documentary, Pierburg: Ihr Kampf ist unser Kampf (Her Fight is Our Fight), police drew and aimed their weapons at these women-one of the various examples of violence directed towards the unarmed strikers. ${ }^{110}$ Elefteria Mermela, a twenty-nine year-old Greek migrant worker, explained that once the police arrived, the foreman pointed her out and the police grabbed her, was forced to lean toward the ground while another officer hit her with a cudgel. ${ }^{111}$ According to her testimony, Mermelaalong with a female and a male colleague - was taken into custody and kept in a single cell for ten hours. In Pierburg: Ihr Kampf ist unser Kampf, Mermela has dark bruises on both of her upper arms, fresh evidence of her interaction with the police on the first day of the strike. The majority of the violence against the striking women laborers took place on the first two days. A heated exchange between Pierburg management and the mass of striking employees outside of the factory gate on Wednesday, August 15 marked the climax of physical confrontation - from August 16 to its conclusion, the police was no longer called upon by company officials to break the strike. ${ }^{112}$

The strike at Pierburg Neuss began on August 13 and ended only five days later, with final confirmation of the strike's success on August 20. Still, the changes as result of the strike were a fraction of the demands put forth by the women on strike. Another multilingual flier circulated within the factory on August 24 noted that the contracts of

${ }^{110}$ As the title of the film suggests, this documentation of the strike was sympathetic to the struggle of the woman migrant worker, as opposed to the media demonization of male migrants during the Ford Cologne Strike. See: Pierburg: Ihr Kampf ist unser Kampf. Directed by Edith Schmidt, David Wittenberg, and Raimund Kirchweger. BRD: Hg., 1974/75.

${ }^{111}$ Braeg, "Wilder Streik-das ist Revolution", 16-17. This interview is also included in Pierburg: Ihr Kampf ist unser Kampf.

${ }^{112}$ Ibid., 35. 
thirty-two colleagues were terminated, with the company complaining that the strike was outsourced or had outside influences and threatened further dismissals if worker protests continued. ${ }^{113}$ The relatively quick resolution of this labor strike was due to the financial pressure placed upon the Alfred Pierburg Automobile Parts Factory (as the assembly line lay motionless during the strike) and the Neuss community's support of the strike.

Woman migrant workers were the primary organizers of the strike, a protest formed with the ultimate goal of abolishing Leichtlohngruppe II. This wage bracket applied only to women, since Pierburg factory policy dictated that women only performed "light industrial work." Therefore, women received 5.28 Deutschmark, whereas men received at least one Deutschmark more. ${ }^{114}$ However, as evident by footage from Pierburg: Ihr Kampf ist unser Kampf, women performed the same tasks as their male coworkers, side by side on the auto part assembly line. ${ }^{115}$

The strike in August 1973 was not the only protest at Pierburg: sporadic strikes had taken place at Pierburg since early 1973 and in June 1973, the tensions at Pierburg spilled over as approximately three hundred workers (both men and women) went on strike, submitting a list of thirteen demands to the factory leadership - emphasizing the abolition of Leichtlohngruppe II and equal pay for men and women as their top two requirements. ${ }^{116}$ This series of strikes is situated at the climax of migrant political and social activism in West Germany. As noted by Miller in "Her Fight is Your Fight," the stagnation of the West German economy led to an increasing unemployment rate, often

${ }^{113}$ Kolleginnen und Kollegen, August 24, 1973, Flier. DOMiD E 0778,0026.

${ }^{114}$ Einsatz Aller Kräfte, 31. 02:53.

115 Pierburg: Ihr Kampf ist unser Kampf. An example of this footage is at timestamp

${ }^{116}$ Braeg, „Wilder Streik—das ist Revolution”, 31. 
meaning that foreign laborers were the first to be laid off or have their wages cut.

Scholars have noted the responses of workers, especially those of women, but Miller points out that scholars often overlooked nationality of those striking. ${ }^{117}$

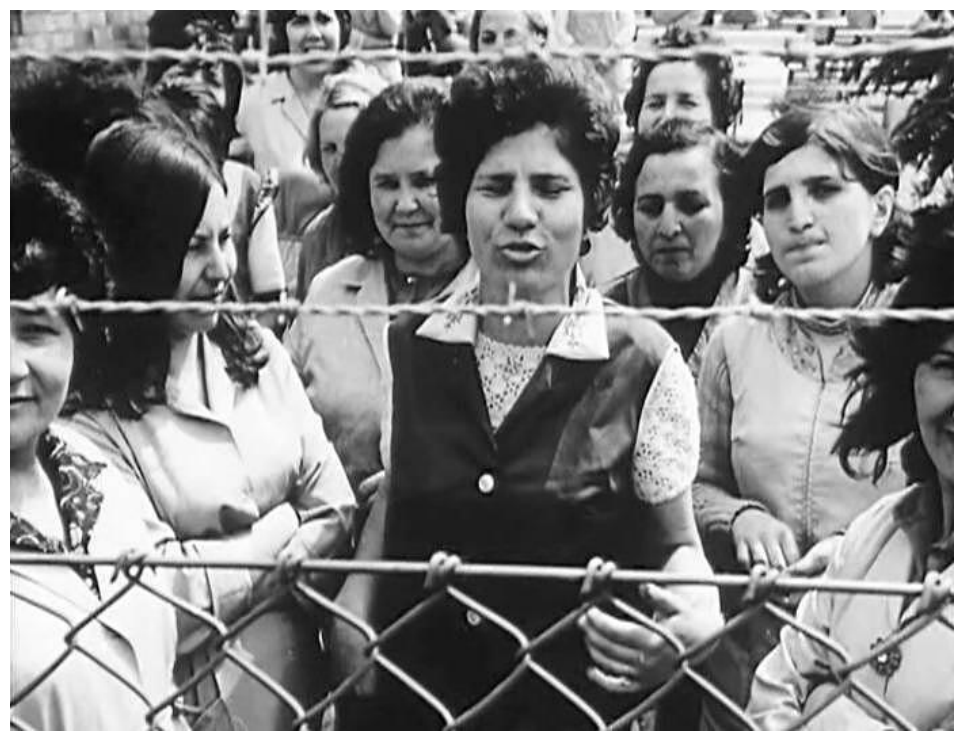

Figure 7. This image is a still frame from the 1974/5 documentary, Pierburg: Ihr Kampf ist unser Kampf (Pierburg: Her Fight is our Fight). These woman migrant workers are standing behind the fencing around the factory, chanting slogans and explaining to reporters the reason they are striking — namely, the abolition of Lohngruppe II and fair compensation for women.

Though the strike was short in comparison to other labor actions in 1973, the events at Pierburg Neuss were well circulated in West Germany. ${ }^{118}$ An entire issue of the Der Spiegel was dedicated to the "Wilde Streiks" (including the Pierburg Strike) affecting Germany during 1973. ${ }^{119}$ In the December 17, 1973 issue of Der Spiegel, television journalists Luc Jochimsen and Lucas Maria Böhmer report on the status of the strike on the ARD broadcasting channel, stating that "women are the Reservearmee (reserve army)

${ }^{117}$ Miller, "Her Fight is Your Fight," 226.

118 The number of specifically migrant strikes in 1973 is not clear, yet at least 562,150 workers participated in at least one strike in the year, with companies claiming 794,806 "lost work days" (Ausfalltage). See: Birke, Wilde Streiks im Wirtschaftswunder: 276 (Table 9).

119 "Wilde Streiks: Lohnpolitik auf eigene Faust," Der Spiegel, September, 31973. 
of the economy...they are "hired and dismissed as [employers] see fit." Jochimsen and Böhmer suggest that this strike was "a historic situation", one where these woman migrants refused to "let themselves be intimidated and fought for their rights through solidarity." ${ }^{120}$ At the time, it appeared that Germans rallied around these migrant workers (at least the women workers) and supported their demands for greater representation and equality in the workplace. However, this reception of the (woman) migrant worker was not the only perspective at the time: as the possibility of integration loomed in the future, many West Germans began to question what constituted a German and if Turkish women migrants embodied the values of the Volk.

\section{The Turks are Coming: The Integration Question}

West Germans began to question what was to be done with the foreign population within the state and whether or not they had to (or should) grant citizenship to those still in the Republic. The implementation of Ausländerpolitik (foreigner policy) as a tangible framework for integration began with the minority political party, the Christian Democratic Union, issuing the Konzept der CDU Ausländerpolitik in 1977, arguably in a bid to garner votes, as the CDU was the majority political party of the Federal Republic until the 1969 elections. ${ }^{121}$ Though the document generated by Christian Democrats marks the first step toward citizenship for migrant laborers within the state, the language of the text was still too vague to offer a concrete solution and thereby highlighted the

120 "Diese Woche im Fernsehen: Ihre Geduld geht zu Ende,“ Der Spiegel, December, 17 1973.

${ }^{121}$ Christian Democratic Union of the Federal Republic of Germany, Konzept der CDU Ausländerpolitik (Bonn, 1977). 
question of what it meant to be 'German'. Nevertheless, many West Germans noted gendered cultural and religious difference as an underlying connection within the ethnic German Volk.

A form of literature focusing on Turkish women migrants as the determinant of compatibility with West German society gained popularity around the end of the guest worker program, but from an unexpected source: West German feminist writers. This genre of Reportage, sought to reveal the oppression and violations against Turkish women living in West German society. ${ }^{122}$ With the increasing popularity of Reportage on Turkish women migrants reflected not only a curiosity into the supposed day-to-day existence of Turkish women living in Germany, but also resulted in an indirect othering of these women at the same time and the vanishing of other Turkish women and girls who did not fit this stereotype. Though West German feminists purported to be allies of migrant women, their work proved more damaging to the image of the Turkish woman in Germany. $^{123}$

This genre of Reportage is difficult to categorize and has maintained popularity into the twenty-first century. Though the documents are purported to be insider stories of the daily struggles of Muslim Turkish women living in West Germany, the authors were often West German feminists writing for a West German audience. These pseudomemoirs include Die verkauften Bräute: Türkische Frauen zwischen Kreuzberg und Anatolien, Gaby Franger's Wir haben es uns anders vorgestellt: Türkische Frauen in der

${ }^{122}$ Reportage can be about virtually any theme, individual, or group of people, but the common framework of these texts follow an 'insider-view' stylistic approach.

${ }^{123}$ For further analysis of the relationship between the women of the metropole and migrant women, see: Antoinette Burton, Gender, Sexuality, and Colonial Modernities (New York: Routledge, 1999). 
Bundesrepublik, Necla Kelek's Die fremde Braut: Ein Bericht aus dem Inneren des türkischen Lebens in Deutschland, the anonymous Ayșe's Mich hat keiner gefragt: Zur Ehe gezwungen - eine Türkin in Deutschland erzählt, and Inci Y.'s Erstickt an euren Lügen: Eine Türkin in Deutschland erzählt. ${ }^{124}$ Due to the anonymity of many of the storytellers, it is difficult to correlate their recollections with primary sources on the condition of Turkish women living in Germany.

While these texts portrayed very real situations and lives, the danger they represent is a continued fetishizing of the trope of the oppressed Middle Eastern woman in Germany, abused at the hands of a zealous patriarchy. Other sources on the development of the image of the Turkish woman migrant in West German society over time include mass media, notably newspapers, including Die BILD-Zeitung, Der Spiegel, and Die Welt. Nevertheless, the popularity of Reportage overshadowed the triumph of the woman migrant worker, including woman Turks, as a self-sufficient agent of change and it compressed experiences of women from different generations into an amalgamous female entity: migrant, Muslim, Turkish, and oppressed under brutal Turkish male dominance.

While the most recognizable photograph of a Gastarbeiter is that of Armando Rodrigues and the most commonly cited migrant labor protest is the August 24, 1973

${ }^{124}$ Gaby Franger, Wir haben es uns anders vorgestellt: Türkische Frauen in der Bundesrepublik. (Frankfurt: Fischer Taschenbuch, 1984); Andrea Baumgartner-Karabak and Gisela Landesberger, Die verkauften Bräute: Türkische Frauen zwischen Kreuzberg und Anatolien (Hamburg: Rowohlt, 1978); Necla Kelek, Die fremde Braut: Ein Bericht aus dem Inneren des türkischen Lebens in Deutschland (Cologne: Verlag Kiepenheuer \& Witsch, 2005); Ayşe, Mich hat keiner gefragt: Zur Ehe gezwungen-eine Türkin in Deutschland erzählt (Munich: Blanvalet Verlag, 2007).; Y, Inci. Erstickt an euren Lügen: Eine Türkin in Deutschland erzählt (Munich: Piper Verlag, 2007). 
Ford Cologne factory strike, imagery from the August 13, 1973 Pierburg strike provokes questions about the agency of migrant women. A strike organized by woman migrant workers challenged the image of the Turkish woman migrant in German society that developed after the Anwerbestopp, one year later. The importance of this image is essential to the debate on integration and the "guest worker question" in West German society. The willful forgetting of the image of the pre-1973 Gastarbeiterin demonstrates the flawed rationale of those in media and politics who pointed to the stereotyped treatment of Muslim-Turkish women as the integration benchmark. The women of Pierburg complicate this image, and their successful navigation to the abolition of Leichtlohngruppe II demonstrates that migrant (Turkish) women cannot be lumped into one group of the oppressed, and that scholars must recognize the importance of the woman migrant worker in labor history, as well to their importance in shaping (West) German politics and citizenship.

\section{Conclusion}

\section{Today's Multikulti?}

A walk through the streets of Cologne today might suggest that integration was the undeniable destiny of former guest workers and German society as a whole. Shop signs coaxing customers in for Döner Kebab and official halal certificates taped in deli storefront windows are as regular as the ever-present kölnischer Wasser sold outside of the Dom. ${ }^{125}$ Any hostility to the over eighty-two million Germans of Turkish descent in

${ }^{125}$ Based on a Turkish dish of the same name, Döner Kebab became a popular street food during the 1970s, though Turkish vendors adapted the recipe to better appeal to German tastes at the time. During the seventies, selling Döner Kebab provided some migrants addition income, while the fast food industry proved lucrative to former guest workers after the recruitment ban. 
the country is, at least, not as overt as it plainly was near the end of the guest worker program in 1974. But to dismiss this moment in German social history would be a disservice to the amount of opposition and rhetoric aimed at the guest worker (including the Turk) and the process was not a clean and painless one. Racially targeted attacks against Turks in Germany occurred with frightening frequency from the eighties to the nineties, with a total of eight Turks slain in acts of arson in Mölln and Solingen. ${ }^{126}$ Included in this number is five members of the same family - two women and three children-who died in an arson fire on May 28, 1993 in Solingen; fourteen other family members were injured in the course of the attack. As evidenced by the arson and murder of an immigrant family in Solingen, xenophobia in the nineties was by no means a bloodless phenomenon. ${ }^{127}$

After 1973, the image of the Turkish migrant worker, specifically the woman migrant worker, shifted, with an emphasis on religious difference as an element of incompatibility with West German values and mores. As described in the chapter concerning the Pierburg Neuss strike, the image of the Muslim Turkish woman served as basis for the exclusion of migrants from German citizenship, with opponents of integration arguing that Islam was irreconcilable with German values. Authors romanticized this image in Reportage on the "hidden" lives of Turkish women in Germany, where West German women and Turkish women "did not speak with one another, — "I don't understand you, you don't understand me" — at best, we deplore

${ }^{126}$ Abadan-Unat, Turks in Europe: 186. See also: Barre Toelken, "Türkenrein und Türken raus: Images of Fear and Aggression in German Gastarbeiterwitze" in Turkish Workers in Europe: An Interdiscipinary Study, eds. Ilhan Basgöz and Norman Furniss (Bloomington: Indiana University Press, 1985), 151-164.

${ }^{127}$ According to the German Federal Agency for Political Education, one hundred and thirty-five foreigners have been killed in xenophobic attacks, as of 2008. 
them, the poor, they with their headscarves, oppressed by father, brother and husband." 128 West German feminists like the author of Wir haben es un sanders vorgestellt, Gaby Franger, not only touched upon patriarchal oppression, but made inferences to religious fundamentalism in their writing as well by highlighting the practice of wearing a headscarf. Franger concludes the book by asserting that "the role of Islam is therefore comparable with the role of Christian religions, which have until recently been the instrument for the oppression of women...we believe [Turkish migrant women] should emancipate themselves, as we have done." 129

The sociological 'clash of civilizations' concept put forward by Samuel Huntington gained traction within German society, influencing not only the general public, but intellectuals, state officials and politicians, as well. ${ }^{130}$ This concept suggests that the meeting of two distinct cultures or religions within a country was not possible without tumult and that peace between the two groups was not possible. In 1981, a group of scholars published a document entitled the Heidelberger Manifest, listing the deleterious effects of the immigrant crisis (meaning the Turkish integration question), citing "biological and cultural" bases for these threats. ${ }^{131}$ As encountered with the Ford Strike, BILD-Zeitung, a right-wing German tabloid, indicated that the continued presence of foreigners, former guest workers, and refugees only served to drain the national social services system, and "thereby destroy the welfare state." Instead of explicit racialized

${ }^{128}$ Franger, Wir haben es un sanders vorgestellt, 95.

${ }^{129}$ Ibid., 102.

${ }^{130}$ James Helicke, “Turks in Germany: Muslim Identity 'Between' States," in Muslim Minorities in the West: Visible and Invisible, eds. Yvonne Yazbeck Haddad and Jane I. Smith (New York: Altamira Press, 2002), 175.

${ }^{131}$ Leo Lucassen, The Immigrant Threat: The Integration of Old and New Migrants in Western Europe since 1950 (Urbana: University of Illinois Press, 2005), 152-3. 
language, culture and religion surfaced in the immigrant question as a justification for the expulsion of former guest workers.

Throughout Turkish-targeted xenophobic attacks and the integration debate of the eighties and nineties, the second generation of Turks were coming of age in Germany. In the eighties, young Turkish-Germans sought to negotiate their space in society and express their differential treatment and pressures. Turkish-German singers, following the surge in popularity in American rap music in the eighties, reclaimed the term 'Kanak' and incorporated it into song. According to Katherine M. Bower's "Minority Identity as German Identity in Conscious Rap and Gangsta Rap: Pushing the Margins, Redefining the Center", artists West Germans of Turkish descent adopted the term into their lexicon and utilized 'Kanak Attak' style rap to express their frustrations and the xenophobia of Germany at the time. ${ }^{132}$ This phrase has lasting importance in the Turkish-German artistic community, with music and art installations carrying the same title today.

${ }^{132}$ Katherine M. Bower, "Minority Identity as German Identity in Conscious Rap and Gangsta Rap: Pushing the Margins, Redefining the Center," German Studies Review 34, no. 2 (2011): 389 . 


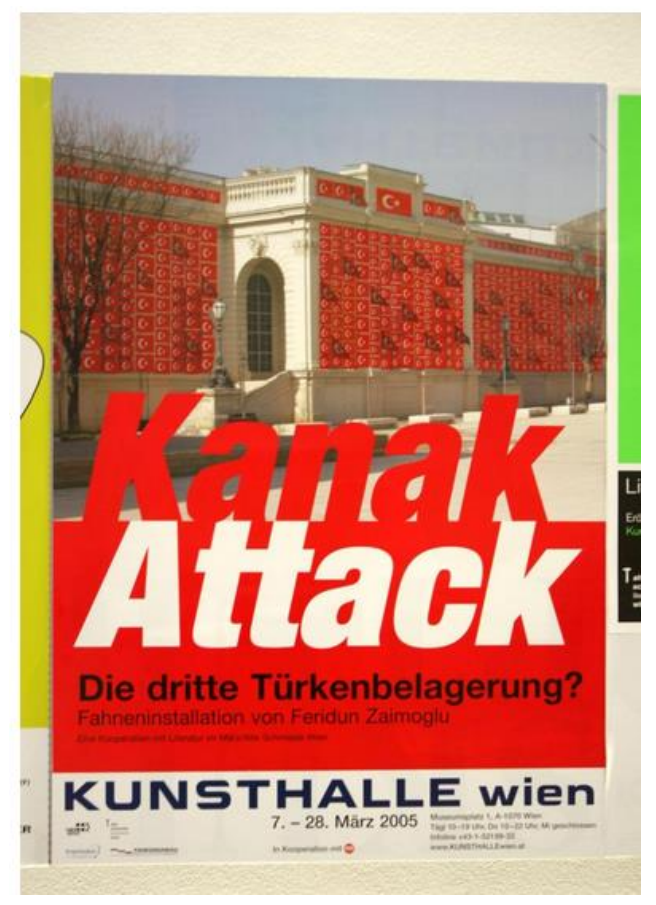

Figure 8. Promotional flier for the flag installation by Turkish-German artist and poet Feridun Zaimoğlu, who came to Germany with his family in 1965. Zaimoğlu's works often deal with the pressures and obstacles faced by second or third generation Turkish-Germans in Germany. Source: Matthias Heine, "Wie 'Kanake' zum rassistischen Hasswort wurde,” Die Welt (18.04.2016).

The remembrance of the 1973 migrant labor strikes is difficult to discern, considering their placement in German history. The strikes occurred in a divided Germany and as is the case for elements of East German history, reunification represented an erasure of liminal experiences. Prior to the Anwerbestopp, migrant labor strikes were intended to reform the guest worker system, but with the abrupt end of the program in November, 1973, any progress the strikes demanded were no longer valid. The discussion shifted from the conditions and treatment of the migrant laborer to the 'foreigner question'. The responses to the 'foreigner question' can be distilled into two answers: send former guest workers and their dependents back to their countries of origin or integrate them. The Gesetz zur Förderung der Rückkehrbereitschaft von Ausländern (Law to Encourage the Return of Foreigners), set forth in November, 1983, promised 
Turkish citizens financial support for their 'return trip home'. Politicians like chancellor Helmut Kohl promoted such program, famously stating, "Germany is not an 'immigration country' (Einwanderungsland)." ${ }^{.133}$ Kohl's utterance portrays the firm belief that the German Volk had little to gain from becoming a multicultural nation.

The memory of the migrant labor strikes in the late-seventies and eighties was then transformed from labor reform to an image of the foreigner in West Germany, or more specific, the Turkish foreigner. As former guest workers lost their limited status as migrant laborers, the photographs of the wildcat strike at Ford painted a raucous and untamed picture of the Turk in Germany. The memory of the Pierburg strike in Neuss faded from the integration debate, precisely because of gendered framing of the strike: since the emphasis of the movement was not upon race or nationality, but gender, this event did not extend as an example of the migrant in German society. Only in the last fifteen years has the Pierburg strike resurfaced in the academic literature, successfully added to the labor history of Germany by scholars including Monika Mattes, Lena Foerster, and Jennifer A. Miller.

Since the late nineties, (the Euro-American community) has lauded Germany as a herald of multiculturalism and tolerance, yet still resistance to foreign bodies comes to head today. After the 2014-15 European migrant crisis, Syrian refugees sought out Germany as one of the preferred nations to claim asylum. In handling the Syrian refugee crisis, chancellor Angela Merkel drew a comparison with the failure of the guest worker

${ }^{133}$ Helmut Kohl, "Regierungserklärung zur 12. Wahlperiode des Deutschen Bundestages" (government declaration, January 30, 1991), Konrad Adenauer Stiftung http://www.helmutkohl.de/index.php?menu_sel=17\&menu_sel2=\&menu_sel3=\&menu_sel4=\&m $\mathrm{sg}=609$. 
program to the crisis. Merkel stated that integration from the start must be the direction in which refugees were handled, unlike the way in which migrant laborers were treated as foreign bodies: "[The focus on immigration] did not happen in the 1970s and 1980s with Turkish guest workers in cities such as Berlin, where for various reasons communities avoided mixing for years, and the consequences are still obvious." ${ }^{134}$ This comparison is significant in that it demonstrates that the history of migrants in Germany is moving from a liminal focus to a primary identifier of the nation. Due to the presence migrant laborers in Germany and their efforts to influence economic and sociopolitical spheres during the seventies, Germany has become, and remains, a multicultural Einwanderungsland.

\section{Bibliography}

\section{Archival Sources}

Einsatz Aller Kräfte, August 7, 1973. Flier. Cologne: DOMiD, E 0778,0028.

HAYM'LERE YAPILAN ZAMLARI PROTESTO EDELIM!, 1974. Poster. Cologne: DOMiD Object no. 8902.

Kolleginnen und Kollegen, August 24, 1973. Flier. Cologne: DOMiD, E 0778,0026. 
Pierburg: Ihr Kampf ist unser Kampf. Directed by Edith Schmidt, David Wittenberg, and Raimund Kirchweger. BRD: Hg., 1974/75.

Strategieplan der Streikenden, 1973, Document. Cologne: DOMiD, E 0727,0001 a-b.

T., Baha. Baha T. aus der Justizvollzugsanstalt Köln-Ossendorf an politische Genossen, 22.9.1975. Letter. Cologne: DOMiD, E 0638,004.

Was Sie vor dem Kauf eines Autos wissen sollten (z.B. FORD), 1973. Poster. Cologne: DOMiD, Object no. 6152.

"Wir bleiben drin, " 1973. Flier. Frankfurt: Häusserrat/AStA. Frankfurt: University of Frankfurt.

\section{Newspaper Articles}

"BILD-Kommentar: Das sind keine Gäste mehr.” BILD-Zeitung, August 30, 1973.

“Die Konjunktur-Kulis proben den Aufstand.” Stern, Nr. 37/1973.

"Diese Woche im Fernsehen: Ihre Geduld geht zu Ende." Der Spiegel, December, 17 1973.

"Eine ehrenwerte Gesellschaft: Offenen Fragen nach der Verurteilung Baha Targüns," KölnerVolksBlatt, Nr. 7/7, July/August, 1975.

"Four Million Workers Migrate in Europe.” New York Times, December 23, 1965.

“Germany Imports Turkish Workers.” The New York Times, October 30, 1963.

"Halbtagsarbeit—wissenschaftlich erforscht," Die Zeit. December 5, 1957.

"Hat es die Erpressung nie gegeben? Zweifel im Prozeß Baha Targün.” Kölner StadtAnzeiger, May 6, 1975.

“Schwere Tumulte bei Ford und Rheinstahl!” BILD-Zeitung (202/35).

Steves, Kurt. “Anwerbestopp bleibt bestehen.” Die Welt, June 13, 1974.

“TÜRKEN-STREIK: Faden gerissen.” Der Spiegel, September 10, 1973.

"Übernehmen Gastarbeiter die Macht? Zum ersten Mal sind sie sich ihrer Stärke bewusst.“ Kölner Express, August 29, 1973). 
“Wilde Streiks: Lohnpolitik auf eigene Faust,” Der Spiegel, September, 31973.

\section{Primary Sources}

Ayşe. Mich hat keiner gefragt: Zur Ehe gezwungen-eine Türkin in Deutschland erzählt: Blanvalet Verlag, 2007.

Baumgartner-Karabak, Andrea, and Gisela Landesberger. Die verkauften Bräute: Türkische Frauen zwischen Kreuzberg und Anatolien. (Hamburg: Rowohlt, 1978).

Brandt, Franz and the Federal Minister for Youth, Families, and Health. Situationanalyse nichterwerbstätiger Ehefrauen ausländischer Arbeitnehmer in der

Bundesrepublik Deutschland. Bonn: Bundesminister für Jugend, Familie, und Gesundheit, 1977.

Bretz, Herbert. "Migration und Integration türkischer Arbeiter und ihrer Familien: Eine empirische Untersuchung am Beispiel der Kölner Ford-Arbeiter." PhD diss., Rheinischen Friedrich-Wilhelms-Universität zu Bonn, 1978.

Clark, John Rosslyn. "Turkish Cologne: The Mental Maps of Migrant Workers in a German City.” PhD diss., University of Michigan, 1977.

Christian Democratic Union of the Federal Republic of Germany. Konzept der CDU Ausländerpolitik. Bonn, 1977.

Franger, Gaby. Wir haben es uns anders vorgestellt: Türkische Frauen in der Bundesrepublik. (Frankfurt: Fischer Taschenbuch, 1984).

Fuest, Anneliese, et al. Möglichkeit und Zweckmäßigkeit der Einrichtung von Teilzeitarbeit für Frauen in verschiedenen Berufen. Gutachten des Forschungsinstitut für Sozial- und Verwaltungswissenschaften der Universität Köln: 1954 (1956).

Kelek, Necla. Die fremde Braut: Ein Bericht aus dem Inneren des türkischen Lebens in Deutschland. Köln: Verlag Kiepenheuer \& Witsch, 2005.

Korte, H. and A. Schmidt. Migration und ihre sozialen Folgen. Göttigen: Vandenhoeck und Ruprecht, 1983.

Krane, R. E., ed. Manpower Mobility across Cultural Boundaries: Social, Economic, and Legal Aspects: The Case of Turkey and West Germany. Leiden: E. J. Brill, 1975.

Narpati, B. "Immigrant Workers in Western Germany." Contemporary Review 208, no. 1203 (1966): 182-186. 
Paine, Suzanne. Exporting Workers: The Turkish Case. New York: Cambridge University Press, 1974.

Wallraff, Günter. Ganz Unten. Köln: Kiepenheuer \& Witsch, 1985.

“Der Streik bei Ford vom 24.8.-30.8.1973” Was tun. Köln: GIM and Betriebszelle Ford der Gruppe Arbeiterkampf, 1973.

Welzel, Ute ed. Situation der Ausländerinnen: Fachtagung am 19.-21. September in Berlin. Berlin: Institut für Zukunftsforschung, 1981.

Y, Inci. Erstickt an euren Lügen: Eine Türkin in Deutschland erzählt. Munich: Piper Verlag, 2007.

Zentralvorstand der Roten Hilfe, Hg. Victor Henry de Somoskeoy: Richter am Kölner Landgericht. Köln: Die Rote Hilfe e.V. Zeitschrift,1977.

\section{Secondary Sources}

Abadan-Unat, Nermin. Turks in Europe: From 'guest worker' to Transnational Citizen. Translated by Caterine Campion. New York: Berghahn Books, 2011.

Başgöz, İlhan, and Norman Furniss, eds. Turkish Workers in Europe: An Interdisciplinary Study. Bloomington, Ind.: Indiana University Turkish Studies, 1985.

Birke, Peter. Wilde Streiks im Wirtschaftswunder: Arbeitskämpfe, Gewerkschaften, und Soziale Bewegungen in Der Bundesrepublik Und Dänemark. Frankfurt: Campus, 2007.

Born, Günther. “'Wie lange sollen wir uns das gefallen lassen?!': Zur Geschichte migrantischer Kämpfe in Deutschland - Der 'Fordstreik' 1973." Lotta 52 (Summer 2013): 58-61.

Bower, Katherine M. "Minority Identity as German Identity in Conscious Rap and Gangsta Rap: Pushing the Margins, Redefining the Center." German Studies Review 34, no. 2 (2011): 377-398.

Braeg, Dieter. "Wilder Streik—das ist Revolution”: Der Streik der Arbeiterinnen bei Pierburg in Neuss, 1973. Berlin: Der Buchmacherei, 2012.

Burton, Antoinette. Gender, Sexuality, and Colonial Modernities. New York: Routledge, 1999. 
Canning, Katherine. "Gender and the Politics of Class Formation: Rethinking German Labor History.” American Historical Review 97, No. 3 (Jun., 1992): 736-68.

Cesarani, David and Mary Fulbrook, eds. Citizenship, Nationality, and Migration in Europe. New York: Routledge, 1996.

Chin, Rita. The 'Guest Worker' Question in Postwar Germany. New York: Cambridge University Press, 2007.

. "Turkish Women, West German Feminists, and the Gendered Discourse on Muslim Cultural Difference." Public Culture 22, no. 3 (2010): 557-81.

Fassin, Éric. "National Identities and Transnational Intimacies: Sexual Democracy and the Politics of Immigration in Europe." Public Culture 33, no. 3 (2010): 507-29.

Foerster, Lena. "Zwischen Integration und Rückkehrförderung - türkische Arbeitnehmer bei den Kölner Ford-Werken 1961-1983,” Geschichte in Köln Vol. 61 (I): 237-70.

Goeke, Simon. "The Multinational Working Class? Political Activism and Labour Migration in West Germany During the 1960s and 1970s." Journal of Contemporary History, Vol. 39, no. I (2014): 160-82.

Goldberg, Andreas, Dirk Halm, and Faruk Șen. Die deutschen Türken. Münster: Lit Verlag, 2004.

Goodman, Charity. "Immigration and Class Mobility: The Case of Family Reunification Wives in West Germany." Women's Studies 13, no. 3 (1987): 235-48.

Göktürk, Deniz, David Gramling, and Anton Kaes, eds. Germany in Transit: Nation and Migration, 1955-2005. Berkeley: University of California Press, 2007.

Herbert, Ulrich. A History of Foreign Labor in Germany, 1880-1980: Seasonal Workers, Forced Laborers, Guest Workers. Ann Arbor: University of Michigan Press, 1990.

"Immigration, Integration, Foreignness: Foreign Workers in Germany since the Turn of the Century." International Labor and Working-Class History, no. 48 (Fall, 1995): 91-93.

Hunn, Karin. "Nächstes Jahr kehren wir zurück... ": Die Geschichte der türkischen 'Gastarbeiter' in der Bundesrepublik. Göttingen: Wallstein Verlag, 2005.

Huwer, Jörg. “'Gastarbeiter' im Streik. Die spontane Arbeitsniederlegung bei Ford Köln im August 1973." Geschichte im Westen 22 (2007): 223-249. 
Kogan, Irena. "Last Hired, First Fired? The Unemployment Dynamics of Male Immigrants in Germany." European Sociological Review. 2004;20(5):445-461.

Lucassen, Leo. The Immigrant Threat: The Integration of Old and New Migrants in Western Europe since 1950. Urbana: University of Illinois Press, 2005.

Mattes, Monika. "Gastarbeiterinnen” in der Bundesrepublik: Anwerbepolitik, Migration und Geschlecht in den 50er bis 70er Jahren. Frankfurt: Campus Verlag, 2005.

Mätzke, Margitta and Ilona Ostner. "The Role of Old Ideas in the New German Family Policy Agenda.” German Policy Studies 6, no. 3 (2010): 119-162.

Miller, Jennifer A. "Her Fight is Your Fight: 'Guest Worker' Labor Activism in the Early 1970s West Germany." International Labor and Working-Class History 84 (Fall 2013): 226-47.

. "On Track for West Germany: Turkish 'Guest-worker' Rail Transportation to West Germany in the Postwar Period." German History 30, no. 4 (December 2012): 528-49.

. "Postwar negotiations: The first generation of Turkish Guest Workers in West Germany, 1961-1973." PhD diss., Rutgers University, 2008.

. Turkish Guest Workers in Germany: Hidden Lives and Contested Borders, 1960s to 1980s. Toronto: Toronto University Press, 2018.

Miller, Jennifer A., and Amy Foerster. "Extranational Spaces and the Disruption of National Boundaries: Turkish Immigrant Media and Claims against the State in 1980s West Germany." Nations and Nationalism 23, no. 4 (October 2017): 83755.

Ohlinger, Rainer, Karin Schönwälder, and Triadafilos Triadafilopoulos, eds. European Encounters: Migrants, Migration and European Societies since 1945. Burlington, Vt.: Ashgate Publishing Co., 2003.

Oltmer, Jochen, Axel Kreienbrink, and Carlos Sanz Díaz, eds. Das "Gastarbeiter"System: Arbeitsmigration und ihre Folgen in der Bundesrepublik Deutschland und Westeuropa. Munich: Oldenbourg Verlag, 2012.

Oetzen, Christine van. Teilzeitarbeit und die Lust am Zuverdienen: Geschlechterpolitik und gesellschaftlicher Wandel im Westdeutschland, 1948-1969. Göttingen: Vandenhoeck \& Ruprecht, 1999.

Rhoades, Michelle K. "Sexual Labor and the Transnational Sphere." Journal of Women's History Vol 27, No. 3, (Fall 2015): 187-193. 
Richards, Yevette . "Labor's Gendered Misstep: The Women's Committee and African Women Workers, 1957-1968." The International Journal of African Historical Studies Vol 44, no. 3 (2011): 415-442.

Rosenfeld, Rachel A., Heike Trappe, and Janet C. Gornick. "Gender and Work in Germany: Before and after Reunification." Annual Review of Sociology 30 (2004): 103-24.

Schönwälder, Karen. Einwanderung und ethnische Pluralität: Politische Entscheidungen und öffentliche Debatten in Grossbritannien und der Bundesrepublik von den 1950er bis zu den 1970er Jahren. Essen: Klartext Verlag, 2001.

Slobodian, Quinn. Foreign Front: Third World Politics in Sixties West Germany. Durham, NC: Duke University Press, 2012.

UNESCO., and International Meeting of Experts on Research on the Status of Women, Development and Population Trends. Women on the Move: Contemporary Changes in Family and Society. Paris: UNESCO, 1986.

“'Wie lange sollen wir uns das gefallen lassen?!': Zur Geschichte migrantischer Kämpfe in Deutschland: Der 'Fordstreik', 1973.” Lotta 52, Summer 2013: 58-61. 